\title{
How do adult beginning Spanish students perceive their teacher's written feedback on their compositions?
}

\author{
Flavia Aoni Costa \\ West Virginia University
}

Follow this and additional works at: https://researchrepository.wvu.edu/etd

\section{Recommended Citation}

Costa, Flavia Aoni, "How do adult beginning Spanish students perceive their teacher's written feedback on their compositions?" (2003). Graduate Theses, Dissertations, and Problem Reports. 720.

https://researchrepository.wvu.edu/etd/720

This Thesis is protected by copyright and/or related rights. It has been brought to you by the The Research Repository @ WVU with permission from the rights-holder(s). You are free to use this Thesis in any way that is permitted by the copyright and related rights legislation that applies to your use. For other uses you must obtain permission from the rights-holder(s) directly, unless additional rights are indicated by a Creative Commons license in the record and/ or on the work itself. This Thesis has been accepted for inclusion in WVU Graduate Theses, Dissertations, and Problem Reports collection by an authorized administrator of The Research Repository @ WVU. For more information, please contact researchrepository@mail.wvu.edu. 
How do adult beginning Spanish students perceive their teacher's written feedback on their compositions?

\title{
by
}

Flavia Aoni Costa

\author{
Thesis submitted to the \\ Eberly College of Arts and Sciences \\ at West Virginia University \\ in partial fulfillment of the requirements \\ for the degree of
}

\author{
Masters of Arts \\ in \\ Foreign Languages
}

\author{
Sharon Wilkinson, Ph. D., Chair \\ Frank W. Medley, Jr., Ph. D. \\ Dara G. Shaw, Ed. D.
}

Department of Foreign Languages

\author{
Morgantown, West Virginia \\ 2003
}

Keywords: Written feedback, Writing, Spanish, Foreign Languages

Copyright 2003 Flavia Aoni Costa 


\section{Abstract \\ How do adult beginning Spanish students perceive their teacher's written feedback on their compositions?}

\section{Flavia Aoni Costa}

Most of the literature on written feedback to date has attended to feedback techniques and the effects of such approaches on students' writing skills. Little emphasis has been placed on students' perspectives on teachers' written feedback. For this reason, the present study investigated how adult beginning students react to their teacher's written feedback on their Spanish compositions. The study used qualitative methods of data collection--questionnaires for the students, interviews with teachers and students and participant observations--in order to explore their reactions and perceptions. The findings show that the general positive reaction students had in relation to their teacher's written feedback was influenced by different factors such as the techniques their teachers used and the acceptance of their teacher's authority. An analysis of the findings was conducted through the perspective of "writing-as-process," which showed that the stages of the process--planning, drafting, revising and proofreading (Gardner, 1996)--were not treated with equal emphasis. Specifically, issues related to content and organization were largely overlooked in favor of grammatical corrections. Implications of these findings are also discussed. 
Dedication

To my parents, sister and brother. 


\section{Acknowledgements}

My eternal gratitude to my family, who has always supported me in every possible way: to my father who never doubted the accomplishment of my dreams, to my mother for being his unquestionable support, to my sister and brother who always fed me with happiness and positive thoughts.

I would like to thank the members of the committee for the dedication and time spent. My honest thanks and admiration to Dr. Sharon Wilkinson, who always provided me with valuable feedback and lessons that, without a shadow of a doubt, will be part of my professional life, to Dr. Dara Shaw for all the help and encouragement during the difficult times not only on my thesis but also during the pursuit of my degree, and to Dr. Frank W. Medley, Jr., for the enlightening and decisive advice on the conduct of my project.

I also wish to thank all my friends who along the process devoted attention and emotional support believing in me. Special thanks to Marina Barros who has always been supportive in every decision of my life in Morgantown, sharing the good and bad times. I would also like to express my heartfelt gratitude to all the students and teachers who participated in this study and dedicated their time and valuable thoughts with the pure intention of helping the realization of this project. 


\section{Table of Contents}

Title page.............................................................. i

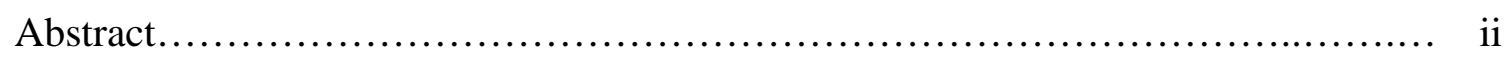

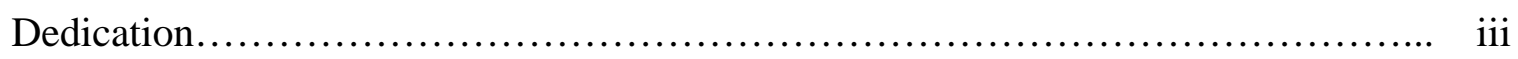

Acknowledgments................................................... iv

Table of contents...................................................

Chapter 1: Introduction and Review of the Literature $\ldots \ldots \ldots \ldots \ldots \ldots \ldots \ldots \ldots \ldots \ldots \ldots$

Introduction.................................................. 1

Review of the Literature........................................ 2

The writing process........................................ 2

Types and effectiveness of teacher written feedback.............. 4

Source of feedback: Peer versus teacher....................... 7

Students' reactions to written feedback.......................... 9

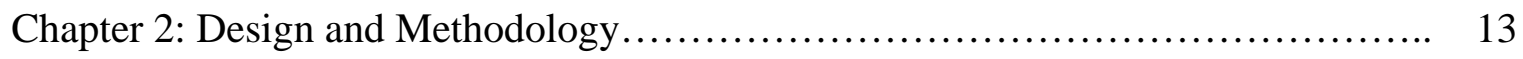

Introduction............................................... 13

Data collection................................................. 14

Data analysis.............................................. 15

Setting................................................... 16

The University and the Spanish course........................ 16

Participants.................................................... 17

Limitations of the study.................................... 33 
Chapter 3: Findings........................................................... 35

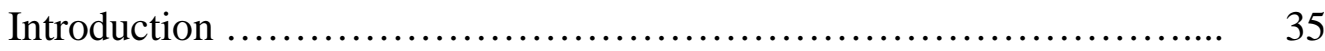

The importance of grades........................................ 35

The importance of grammatical accuracy............................. 38

Direct versus indirect feedback.................................... 41

Student-initiated feedback.......................................... 47

Acceptance of the teachers' authority ................................ 50

Chapter 4: Discussion and Conclusion....................................... 56

Discussion....................................................... 56

What happened to the writing process? ........................... 57

Conclusion ...................................................... 59

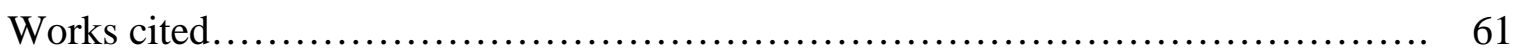

Appendix A: Grading Criteria .................................... 64

Appendix B: Demographic Questionnaire........................... 66

Appendix C: Interview \#1 with students............................. 68

Appendix D: Interview \#2 with students ........................... $\quad 70$

Appendix E: Questionnaire........................................ 72

Appendix F: Interview with teachers.............................. 74

Appendix G: Typo de Errores [Type of Errrors] ........................ 76

Appendix H: Guía para la Composicón [Guide to the Composition]...... 78

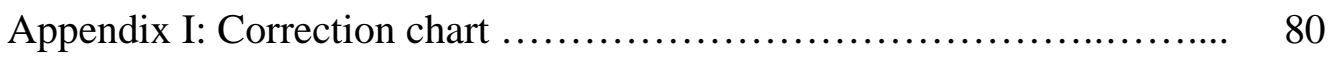

Appendix J: Course objectives .................................... 82

Appendix K: Compositions.......................................... 84 


\section{Chapter 1}

\section{Introduction and Review of the Literature}

\section{Introduction}

By focusing attention on the learner's role in the writing process, this study looks at feedback from the students' point of view. Specifically, the study explores their perceptions, reactions and expectations regarding teachers' responses to their written work. Teaching writing as a process allows teacher intervention as students and teachers negotiate meaning. Feedback is one step in the process, during which the teacher and students can read and respond to the writing as it develops into the final product.

Lamberg (1977) simply defines feedback as "information on performance" (p. 1). He states that "feedback can be responses from a classmate to one's writing as well as comments and corrections by a teacher" (p. 1). Additionally, he notes:

Effects may be to increase (or strengthen), decrease (or weaken) or maintain the performance. This definition can include practices like “marking," "correcting," and "grading." The definition can also be related to alternative practices, such as responding to a student's writing without noting errors, and having students measure their own writing. (p. 3)

Teacher feedback is part of a larger context of different types of feedback on writing that may also include peer feedback, class or group discussion, or other sources of information. Nevertheless, the teacher still seems to be the primary source of feedback in the classroom.

In general, researchers have not adequately investigated how students react to their teacher's written feedback. According to McGee (1999), "one of the major reasons 
that student reaction has not been fully explored is that many of the empirical projects to date have been quantitative instead of qualitative" (p. 23). With the purpose of more deeply understanding students' perspectives on teachers' written feedback, this study used qualitative techniques to investigate: "How do adult beginning Spanish students perceive teacher written feedback on their compositions?" The study serves as a channel for the students' voices to be heard, giving them a chance to express their opinions and perspectives related to their teacher's written feedback, and it offers teachers and researchers a chance to hear those voices, which have not often been elicited.

\section{Review of the literature}

\section{The writing process}

New directions in writing defend the idea of writing as a process where teachers and students interact with the objective of improving the quality of the text through revision. Zinsser (1988) states that:

A piece of writing must be viewed as a constantly evolving organism. Curiously, this hasn't been the prevailing theory in our schools. American children have long been taught to visualize a composition as a finished edifice, its topic sentences all in place, its spelling correct, its appearance tidy. Only lately has there been an important shift. The shift--in the terminology of the trade--is from "product" to "process." It pushes the emphasis where it should have been all along: on the successive rewritings and rethinkings that mold an act of writing into the best possible form. If the process is sound, the product will take care of itself. (p. 16) Gardner (1996) suggests four main steps for the writing process: 
1) Exploring and planning: discovering, focusing, finding support for, and organizing ideas; 2) Drafting: getting ideas and supporting details down on paper in rough form; 3) Revising: rethinking and rewriting drafts to improve the content, focus, and structure; 4) Editing and proofreading: checking for effective word choice and sentence structure, as well as correct grammar, spelling and mechanics. (p. 233)

Gardner also talks about the importance of the writer's conceptualization of audience. He explains that the writer should know who his/her readers are, their characteristics, such as "age, sex, ethnicity, occupation, educational background, or political beliefs," as well as their "interests, needs, and expectations" (p. 246). Walvoord (1986) discusses the teacher as the students' audience:

We find it easy to assume that our students know how to write for the instructor who is standing before them, giving them the topic, length, and due dates.... Many papers are poor because students assume our [the teachers'] knowledge of things that they should have explained or because they spell out details that we would have taken for granted or because they adopt a tone we find too familiar or too stuffy or too affected. These errors all reflect misjudgments about what the audience--the teacher--needs or likes. We could help our students greatly by being more specific about ourselves as audience. (p. 20)

Walvoord also points out that teachers are often simultaneously the audience and the evaluator for student writing; thus their feedback may reflect either or both roles. Some of the types of written feedback used by teachers and their effectiveness on students' writing are presented in the next section. 


\section{Types and effectiveness of teacher written feedback}

Types and effectiveness of teacher written feedback are the topic of most writing studies related to feedback. Most of these studies relate the type of feedback to its consequent effectiveness. Lamberg (1977) says that

Written feedback may be categorized as abstract or specific, as positive, negative, or corrective, and as task related to task unrelated. The amount of feedback given may be important, as may be the conditions by which feedback is provided and the source from which it comes (teacher or peer). (p. 1)

He claims that positive feedback has greater effectiveness over negative feedback in improving writing performance.

In a different analysis Ferris and Roberts (2001) categorize written feedback as direct and indirect. They state:

Direct feedback is given when the teacher provides the correct form for the student writer; if the student revises the text, he/she needs only to transcribe the correction into the final version. Indirect feedback occurs when the teacher indicates in some way that an error exists but does not provide the correction, thus letting the writer know that there is a problem but leaving it to the student to solve it. (p. 163)

In a study that aimed to test the effectiveness of indirect feedback in combination with other feedback techniques in an intermediate German composition course, Lalande (1982) concluded that "the combination of error awareness and problem-solving techniques had a significant beneficial effect on the development of writing skills" (p. 145). 
In her research with college intermediate Spanish students in a foreign language writing course, Kepner (1991) sought to compare two types of written feedback (grammatical corrections and message-related comments) with regard to their effects on students' writing improvement. She divided her subjects into two groups and provided one group with surface-level error corrections only and the other with message-related comments and no error-correction. Both groups progressed at the same rate with regard to accuracy, but the students who received message-related comments out-performed the grammar correction group in the complexity of their thoughts, regardless of overall language learning ability. She concluded that "error-correction" and "rule reminders" were "ineffective for promoting the development of writing proficiency in the L2" (p. 310).

Based on the concern for feedback effectiveness in general and for its specific effects on the overall quality of students writing, Ferris and Roberts (2001) conducted a study to investigate 72 university ESL students' feedback preferences. Students were divided into three different groups. Group A had all their errors underlined and coded in categories such as verb errors, noun ending errors, article errors, wrong word and sentence structure. Group B had all their errors underlined but not coded, group C received no marks in their compositions. The results were described as follows:

As to feedback preferences, no respondent said that s/he did not want any error correction (the treatment received by Group C). The most popular feedback choice (48\%) was for the teacher to mark the error and label it with an error code (i.e., the treatment received by Group A in this study), followed by having the teacher correct all errors for them (31\%). Only 
$19 \%$ said that having errors marked but not labeled by error type (the

group B treatment) was preferable to other feedback methods. (p.173)

The study concluded that the groups who received some sort of feedback performed better than the group with no feedback, but there was not a significant difference in performance between the "code" and the "no-codes" groups.

In his study of students' apprehension related to the writing process, Wiltse (2001) categorized feedback as either global or local. Global feedback is related to the content, organization and development of the text, and local feedback is related to the mechanical part of the text. The experiment used a statistical test to evaluate if students used more local or global feedback depending on their level of apprehension and outcomes. No significant differences were found between the use of one type of feedback or the other. Wiltse also concluded that "writing apprehension seems to be more common in poor writers, although it is possible that poor writing skills may lead to writing apprehension" (p. 2).

Conrad and Goldstein (1999) stress the fact that in order to understand the student's process of revision and feedback effectiveness, it is important to consider individual factors affecting students, as well as the types of changes they are asked to make, and not only the comments themselves. This conclusion came after a study with an advanced ESL composition course where the researchers analyzed whether the types of comments the instructors made on students' compositions led to success or lack of success after students' revisions. The conclusion was that the types of comments were not as important as individual factors such as "misinterpretation about what certain 
comments ask for, limited content knowledge, as well as limited instruction in using and finding content, and strongly held beliefs" (p. 162).

Considering the different techniques used to provide written feedback, their effectiveness can also be related to their sources, as students may react differently to it depending on where the feedback comes from. Besides the teachers' feedback, other forms, such as peer feedback, have also been widely used in classrooms.

\section{Source of feedback: Peer versus teacher}

Several studies related to feedback on compositions have been conducted with their emphasis on peer-response in the ESL and FL classroom (Amores, 1997; Hyland, 2000; Long, 1992; Paulus, 1999). Some of these studies make a comparison between students' preferences for peer or teacher feedback, and many of them show that in general students value the teacher's feedback more than feedback from their peers.

Amores (1997) conducted an ethnographic study of students' perspectives on peer feedback on writing with eight undergraduate American students in a third-year Spanish classroom review course. She concluded that students orient to the peer-editing process as a social interaction with their colleagues, one that involves emotional and hierarchical issues among the participants. Moreover, students participate in the peer-editing process because it is required by the teacher and not because they believe it to be an activity that would help them improve their linguistic skills. As she explains: "It is possible that they interpreted critical comments as appropriate for the teacher only, and were careful to differentiate their speech from that of the instructor" (Amores, 1997, p. 516).

In an investigation of peer response and instructor commentary in and out of class, both on written and oral feedback in Spanish as a second language, Long (1992) 
concluded that students expressed their preference for teacher feedback as the one that benefitted their writing the most. The investigator attributed this finding to the fact that students see the teacher as the authority of the class and that his/her comments are consistent. But students also "pointed out that peer feedback was very useful in revising their assignments--as long as their peers made sincere efforts to supply useful feedback" (p. 16).

Giberson (2002) defends the idea of a collaborative text as opposed to teachers imposing what they think is right: "By crossing out student text and rewriting it, the teacher ceases to be a reader of a text, and becomes a rewriter" (p. 411). These findings bring to evidence an interesting point discussed in the literature: the "ownership" of the text. When students make changes to their text based on what the teacher wants and not on their own ideas, then whose text is it? It seems, however, that many students are quite willing to relinquish ownership, as Cavalcanti and Cohen (1993) note: "Learners may make changes according to what they think the teacher's values are, out of a belief that the teacher knows best" (p. 84). Dohrer (1991) found that students' efforts to ameliorate their compositions based on teachers' comments were motivated primarily by grades. Students tended to make only superficial changes to their compositions based on what they perceived the teacher wanted according to the comments they received.

Hyland (2000) specifically investigated through a qualitative study the issue of ownership and text revision by two ESL students. As a solution for this problem of teachers usurping ownership through their corrections, the author defends the idea of peer feedback, saying that students can choose to reject the teacher's decisions and have more freedom to decide whether or not to incorporate their peer's suggestions. 
Opposing the idea that students base their changes during revision primarily on their teachers' comments, Marzano and Arthur (1977, as cited in Cohen, 1987) found that $10^{\text {th }}$ grade English-native-language writers “did not read the teacher's comments or read them but did not attempt to implement the suggestions and correct the errors" (p.16).

The literature presented in this section suggests that students consider their teacher's feedback more important than their peer's in most cases. Students seem to see in their teachers not only the person that knows more but also the authority that can improve their grades. In spite of this assertion about students' preferences regarding written feedback, little has been done to investigate their views. Some of the few studies conducted with this purpose are presented in the following section.

\section{Students' reactions to written feedback}

Only a few studies on teachers' written feedback have had their main focus on students' reactions to teachers' written feedback. Some of the studies considering this issue concluded that students see the need for revision as an indication that their work was not well done the first time and that it needs, above all, to be corrected. As Lehr (1995) states, "students often see revision not as an opportunity to develop and improve a piece of writing but as an indication that they have failed to do it right the first time. To them, revision means correction" (p. 3). Lehr believes that teachers should value the content of the papers and make students involved in the process of revision. Support for this idea is found in Hyland and Hyland (2001) who state: "Several L1 studies suggest that teachers attend to error more than excellence and tend to focus their feedback on the negative aspects of the writing" (p. 187).

Following the same idea, Cavalcanti and Cohen (1993) state that 
There may be a misfit between written feedback teachers provide on compositions and learners' genuine interests--between what the teachers give and what the students would prefer to get. Part of the problem may lie in the nature of the teacher's feedback, namely, that it may frequently be unclear, inaccurate or unbalanced--both by focusing only on certain elements in written output (e.g., grammar and mechanics) and by overemphasizing negative points.... The student writer and the teacher do not necessarily share common information, skills, and values when they interact. (p. 84)

In a qualitative study on feedback on writing with ESL students, Hyland and Hyland (2001) found that some students think that positive comments are useless and insincere. One of them said that it was most important for him to know his weaknesses. On the other hand, some students found positive comments motivating. The authors emphasize the fact that students were often unable to understand the teachers' comments. Similarly, Ferris (1995, cited in Hyland \& Hyland, 2001) argues that "studies of L2 students' reactions to teacher feedback show that learners remember and value encouraging remarks but expect to receive constructive criticism rather than simple platitudes" (p. 187).

One of the few studies that considered the students' point of view was a case study in first language writing conducted in Brazil by Cavalcanti and Cohen (1993). Their project investigated the relationship between the feedback provided by the teacher on compositions, the students' thoughts about the comments, and what they did with this feedback. The teacher was a native speaker of Portuguese as were the students, who were in a remedial sixth grade class. Students wrote dialogues where they talked to a 
friend about their own jobs. After the teacher gave written feedback on the students' writing based on grammar, mechanics, vocabulary, organization, and content, students had the opportunity to talk about it. Some of the students' reactions to the feedback were very similar. Most students showed preference for feedback on mechanics rather than on organization.

An important qualitative study conducted in the students' first language by McGee (1999) explored English 102 students' affective response to teacher-written comments, how students negotiated those comments, and how they used them during revision. The results showed that all subjects reacted emotionally in some way to the teachers' comments but that none of them had a strong emotional response. Furthermore, students revised their texts with the teacher's response in mind, equating pleasing the teacher with obtaining a better course grade. For this reason comments that were perceived as unclear, that addressed issues seen as unrelated to the writing, or that centered on the teacher's opinion were least helpful and often discouraging for the students.

In a similar study, Veerman (1999) found contrasting results with McGee's (1999). She explored students' reactions to teacher response on writing assignments and examined how they perceived and used written and oral teacher response in their revision process. Students were enrolled in an English 329 course in a Continuing Education Program of a private university in Florida. The study found "that all participants perceived teacher response as necessary and helpful for their learning and growth as writers.... Students saw response on ungraded drafts that they revised before receiving a grade as opportunities to use what they were learning and to improve their writing" (p. 1). 
Through McGee's (1999) and Veerman's (1999) contrasting results we can see that students' views on their teacher's feedback can be quite varied.

Through this review of the literature, we have seen that, while most research about written feedback on compositions emphasizes teachers' approaches to providing feedback on students' written work and the influence of that feedback on student performance, far less attention has been devoted to describing students' reactions and feelings towards their teachers' written comments. For this reason this study proposes to explore this perspective through students' perceptions of and reactions to the teachers' feedback on their Spanish compositions. The next chapter presents a detailed description of the design of the study and introduces the participants and the setting. 


\section{Chapter 2}

\section{$\underline{\text { Design and Methodology }}$}

\section{Introduction}

Because the main objective of this study was to explore and describe what students' perspectives on written feedback are, a qualitative approach seemed to be the most appropriate for the study. The need for a qualitative approach can be justified by the fact that this study aimed to explore in depth a complex process, namely, the writing process. Also, the research tried to investigate a little-known phenomenon, the students' perceptions of feedback. Marshall and Rossman (1999) stress the fact that qualitative methods are appropriate for "research that is exploratory or descriptive and that stresses the importance of context, setting, and the participants' frames of reference" (p. 58).

The data collection techniques used in this ethnographic research--ethnographic interviews, demographic questionnaires and participant observations--serve the purpose that Marshall and Rossman (1999) explain: "one cannot understand human actions without understanding the meaning that participants attribute to those actions--their thoughts, feelings, beliefs, values, and assumptive worlds" (p. 57). The importance of "face-to-face interaction" with the informants' world, through ethnographic observations, is justified by the assertion that "human actions are significantly influenced by the setting in which they occur; thus, one should study that behavior in real-life situations" (Marshall \& Rossman, 1999, p. 57).

This chapter describes in detail the data collection techniques used for the present study, as well as the procedures for analyzing the data. Following those descriptions, the time frame of the study and its setting and participants are presented. 


\section{Data collection}

The data collection for this investigation took place during the second summer session of 2002 at Regency University ${ }^{1}$. Two groups were involved in the investigation: one Spanish 101 group and one Spanish 102 group. A demographic questionnaire was initially given to all students in each group who agreed to participate in the research project, so that I could have an overall idea who the potential participants were, even though not all of them were selected as primary informants. The questionnaire was used to gather information such as age, gender, and language background of the participants. (see Appendix B)

Using this initial questionnaire, I selected six participants from each class, with whom initial interviews were conducted, focusing on topics related to students' past experiences with the language, their general impression of the acquisition of a second language, their language learning experiences, and their motivation. The selection of these informants focused on maximizing the variety of perspectives available (e.g., different age groups, gender, language and cultural backgrounds, etc.) (A sample of the interview questions can be found in Appendix C.)

From the first interview, a total of three students from each class were selected to serve as primary informants in the investigation, depending on their willingness to participate and on the relevance, for the study, of the perspectives they could offer. The second and third interviews were about the drafts of the essays. The interviews were expected to elicit students' opinions and perceptions toward the teacher's feedback on their drafts and final compositions. (A sample of the interview questions can be found in Appendix D.) I read and kept copies of the drafts and final compositions made by the

\footnotetext{
${ }^{1}$ Pseudonyms have been used for all people and institutions to protect anonymity.
} 
students as one of my sources of data. (A sample of the drafts and final compositions can be found in Appendix K.)

A questionnaire using the same type of questions as the ethnographic interviews was also given to the whole class after the teacher gave back the first draft in order to provide a larger context in which to situate the primary informants' views elicited in the interviews. (see Appendix E)

Interviews with the teachers regarding their feedback practices and teaching strategies were also carried out. Their perspective provided additional insight into the phenomena under investigation. (A sample of the interview questions can be found in Appendix F.)

I observed the classes every day during the first week of classes and once a week after that in each class. In the class observations, I tried to become familiarized with the participants' learning environment, the teaching style, and the participants' behavior in this setting and the general atmosphere of the class in order to better understand informants' perspectives.

\section{Data analysis}

The data included in the analyses came from the questionnaires, copies of compositions, ethnographic interviews and observation notes. The tape-recorded interviews were transcribed word-for-word, and I analyzed the transcripts by coding the data for salient themes. The analysis was based on features previously presented in the review of the literature, such as the different types of feedback. I typed the observation notes right after the observations occurred, so that information could be added or described in better detail. I then copied these notes so that I was able to use different 
coding methods like margin notes and color-coding. The original was retained for my files. The questionnaires, which provided important background information about the students, were also analyzed for converging information.

Students' compositions served as a basis for what was said in the second and third interviews and helped to better understand students' perspectives. They also helped situate what teachers said in the interviews about their feedback strategies.

\section{Setting}

\section{The University and the Spanish course}

Regency University is a large, state-supported research institution located in the eastern part of the United States. It has 13 colleges and schools that offer 169 bachelor's, master's, doctoral and professional degree programs. The university has an enrollment of about 21,000 students, who come from different states of the U.S. as well as from many other countries.

Through its Department of Foreign Languages the University offers undergraduate course work in Spanish, German, French, Italian, Japanese and Russian. There are about 2000 students in the lower-level Spanish program, consisting of 4 courses, divided into about 80 sections. Each class has about 25 students. (The course objectives for Spanish 101 and 102 can be found in Appendix J.) Most of the teachers in these classes are Graduate Teaching Assistants that are at the same time pursuing their Master's Degrees at the University.

The orientation for the beginning GTAs includes, among other topics, workshops about the writing process. In the workshops they have a detailed lecture on writing process versus product. During the training, they are given samples of student writing to 
practice grading, and they have also to justify their comments on the paper; the workshop leader then evaluates their feedback. After that, they are taught how to apply the grading criteria used in the course to give students feedback on their compositions. (The grading criteria for compositions can be found in Appendix A.) Besides this initial training during orientation, students learn more profoundly about the theories related to the writing process and how to evaluate writing in their teaching methodology class, which is part of their Master's program. During the time that the GTAs are teaching, they have additional periodic meetings with their supervisor, some of which are also exclusively related to the evaluation of students' writing.

In Spanish 101, students have to write a composition as one of their requirements for their course grade, and, in Spanish 102, they have two composition assignments. Students have to write one draft before the final version of the composition. (see Appendix K) The teacher provides feedback on the first draft and evaluates it according to the grading criteria. Based on this information from the teacher, students make changes for the final version, which is also graded. Evaluation is based on content, organization, vocabulary and language.

In addition to the composition, course grades are based on class participation, written and oral exams, quizzes, and homework. The compositions in both, Spanish 101 and 102 are worth $15 \%$ of the students' final grade.

\section{Participants}

The majority of participants in this study were native speakers of English--college undergraduate students enrolled in Spanish 101 and 102 classes. Each class had an enrollment of about 20 students. Most of the students in these classes had similar 
background knowledge of Spanish, since to take this course students are required to either take a placement test or to have taken the same prerequisite. Students enrolled in the Spanish 101 class either have no prior knowledge of the language or have been placed in this level after taking the placement test. As for Spanish 102, students have to either have taken Spanish 101 or the placement test. Many students were in these classes as a requirement for their undergraduate major; some planned to major or minor in the language.

\section{Primary informants}

\section{Spanish 101}

\section{Josh}

Josh, a 23-year-old senior majoring in horticulture, considered himself to be a serious student:

...the reason I have done so well on my exams and quizzes is just because I do the work. Luisa [the teacher] does not make anybody do their homework so I think I have to apprehend by doing my homework, being prepared so I hardly study and I still do well because most stuff in the quizzes and tests come straight from our homework, exercises that I did yesterday--two days ago--or I have at least done them so I had to apprehend choosing to do my homework whereas everybody comes and sort of looks at the exercises, still opening their books and then Luisa calls on them, they look at her and they say "OK", and it takes some more minutes until they figure out, while I was sitting there last night doing it, so I think that helps a lot.

He explained his perspective about the class: 
It is pretty straightforward--I mean, it is about what I expected. It is not too hard; the teacher seems very enthusiastic about us learning, which is good, you know, some teachers just do not care. When we do not get it, she seems to get upset. I like that. She is enthusiastic--I do not know if that's the word, but she seems to want us to learn.

Josh took German in high school and he would often compare his experiences learning German and those learning Spanish:

One thing that I learned from taking German is... nobody is going to laugh at you for saying "muchas" [a lot] if you are a man or something like that. They will still understand so I do not think that's important to learning a language. It is more being able to be understood so if I say "muchos personas" [a lot of people] they still know that I am talking about many people, it just might sound a little different.

His main objective with learning Spanish as he said was "to be able to get the respect of my co-workers." He explained that in his field--horticulture--many of the people are Spanish speakers. Because of that, for him, knowing how to write well was not as important as speaking well: "Well, writing is more important I guess because it is more formal, but, I mean, I do not see myself doing a lot of writing in Spanish but more speaking, more to do with the kind of guys I will be dealing with."

\section{Anna}

Anna was a psychology major and like Josh, was taking Spanish classes not only to meet the requirements for her Bachelors' degree but also to be able to communicate in 
Spanish: "I want to learn so that I can speak to my friends, like e-mail them and stuff like that. Once I learn a little bit more I will probably start e-mailing them in Spanish."

Her contact with Spanish before studying it at the university was in high school where she studied the language for two years and with her Colombian friends:

They are from Colombia, and I met them last year--beginning of my junior year-and I hung out with them like all year, so I got to hear Spanish like all the time and I could pick up some of the things that they were saying.

Her experience with Spanish in high school on the other hand, did not seem to have given her as much knowledge of the language:

When I was a freshman and sophomore in high school I had Spanish 1 and $2 \ldots$. In high school we cheated a lot on tests and stuff like that, so I learned a little bit. It is like a review for me, the first chapter.

Anna's voice was constantly heard during the classes. The direction of her attention was at times toward the classmates sitting around her and frequently toward the teacher with questions about the subject or general information about the classes, like due dates for assignments. In class she was usually "talking to my neighbors... or I like to do the workbook. Like today, when she handed out our paper she was explaining it [the corrected essay] but I was looking in the book and translating it as we were going." The process of writing for her did not seem to be a complicated one: "I did it [the composition] the night before it was due in like an hour... it was not a long process for me."

Anna was not the only one who had contact with native speakers of Spanish outside the classroom. Her classmate Yukiko had this experience with her co-workers. 


\section{Yukiko}

Yukiko was the only non-native speaker of English among the participants. She was a graduate student from Japan and even though her major was Fine Arts, she worked in a computer laboratory at the University: "That's just my passion, technology, education.” In the lab, she had many co-workers who were native speakers of Spanish. Even though she preferred listening to their Spanish, her only attempts to use the language with them was to say things like: "Hola” [Hi] or “¿Cómo está?” [How are you?]. She was also interested in learning about her friends' culture: 'I want... to understand where my friends are coming from and what their cultural background is."

Besides being able to communicate in Spanish she wanted "to be able to watch TV programs, listen to the radio or even read information on the internet." She mentioned that because she had learned English before, learning Spanish was easier: “... most of the words are very similar or I can associate or I can guess some words through English but not from Japanese by any means." Maybe because her main objective was to be able to communicate orally in Spanish, writing compositions for her did not seem to be an exciting activity, especially at her level. She explained that she likes to write compositions when "the topic is interesting" when the topics that are "thought provoking," "like why this is wrong and this is right." She added that, unfortunately "the level of the topic that I can choose comfortably and have enough vocabulary to write about is very boring."

An interesting fact about Yukiko is that she learned German by herself. She was also at the time of the investigation taking German classes at the university. She explained that with the classes she would improve her speaking skills since what she had 
learned by herself was mostly grammar. In her opinion it was important for students to participate in the class: "I think we should ask questions, it is important to ask questions." About her participation in the Spanish classes she said: "I will participate moderately, I guess not like really, really enthusiastically, no, but when I feel like, then I will."

Yukiko’s experience learning Spanish seemed to be different from Henry's, who, like most of the students in the two groups, was studying Spanish as his first foreign language.

\section{Henry}

Among all the participants, Henry was the one who made no restrictions about his schedule in order to be interviewed for the study. He was also the one who was interviewed the most times and with whom I had the longest interviews. In our first interview, he summarized his experience with Spanish: "My first Spanish 1 class was when I was a freshman, so I've had two years off, so I am just now getting back into it. But I am catching up pretty quick I think.”

Henry expressed that he would like to learn Spanish to live in a Spanish-speaking country or "a city in the United States where the majority of people speak Spanish." His dream was to be part of the Federal Bureau of Investigation, a job in which knowledge of Spanish might be helpful. As for his major--accounting--he said that knowing Spanish would not be as important.

Henry sat in the back of the classroom and always had all of his materials with him in the class as well as his homework done. He said the teacher explained himself well and complimented him, saying that "he is a real nice guy." He also appreciated the group work in class and worksheets that the teacher designed. 
He seemed to give considerable importance to the vocabulary. In class, he liked to "follow the pictures [in the book] and, like, look at the words he [the teacher] is saying. I take down like all the vocab and translation "cause I like to learn the vocab...." Vocabulary was also central to his writing strategies: "I think about what I am going to say in English, I write the paper in English, and then try to translate it. I usually go to the glossary in the book and then to the Spanish-English dictionary."

\section{Laura}

Laura, as opposed to her classmate Henry, was considerably older than the others in her class. She was an English major and her experience learning Spanish was apparently influenced by the perspective she had of being an older woman in a classroom with students who had just entered the university: "Most of them may have had Spanish in high school which is not too far in the past for them." From her point of view, the age difference was the reason for the lack of interaction between her and her classmates: "I do not know anyone in class. They do not seem particularly interested in knowing an older person." She was one of the few students who went to the teacher's office hours to ask for help.

For our second interview she suggested that we go to the library to talk in one of the study rooms. We started our conversation talking about her previous experience with a foreign language:

The only experience I have with a foreign language is... two or three years ago our whole family went to Germany. My son was over there for four months for school, and we met him at the end, and... he was able to converse, but it would be 
nice to be able to understand and correspond, talk to people directly instead of going to your friends or kids.

She expressed regret for not participating in the classes: "He did give opportunities to speak but I did not take them, and I wish I had earlier on because I am still not very much comfortable pronouncing." Later she explained "I am very reserved, and I do not volunteer. It is just my nature." She commented on her perspective of the class:

I do not find the professor any easier to understand. Even though he brings the point that he is trying to make clear by other actions, I never know what he is really saying. I find that frustrating. I guess the main idea of what he wants, but I really do not know what he says.

The composition did not seem to be as challenging for her as participating in the class: "I did well in composition whereas in the exams or the class, I do not do that well." The positive view she had about the composition seemed to be related to the fact that she had a good grade on it: "On each of the grading criteria he gave me one next to the highest, so I wasn't exactly real good but I was fairly good.” In spite of the age difference, Laura and Angela seemed to have similar goals for learning Spanish.

\section{Angela}

For Angela, even though taking Spanish was a requirement for her Communication major, she expressed that she would like to know how to speak it in order to travel, and also because in her opinion, it could help her get a job. Angela always looked attentive in the class and seemed to understand what her teacher was explaining, but she also felt uncomfortable with his approach: 
One thing that bothers me is that he does not like when you have your notebook open and you are taking notes, and I am trying like to sneak notes because I have to write stuff down or I 11 forget it, so usually I am just either writing things down or trying to remember something he said or following along with my book.

In spite of this frustration, she felt fairly confident in her ability to understand the lessons: "I think I can follow OK while I am in class." Doing her homework however, was a different story:

When I go home I have a problem figuring out what is wrong by myself... I can follow the teacher when he is talking and stuff like that but when I try to do it on my own I have more trouble.

She emphasized the help she had from her roommate when she was studying at home: "My roommate is very good in Spanish, so she helps me a lot with my homework. She explains the directions to me and checks over my work to do the whole workbook instead of just what she assigns." Besides her roommate's help, Angela mentioned using additional learning sources: "I listen to the CDs a lot... I do, like, a lot of work in the book because if I do not keep up with it I will forget. It is just... it is hard for me to learn a language." She revealed later that she was reluctant to speak in class: "I am afraid of sounding stupid, like pronouncing something wrong." I asked if she could maybe practice with her roommate, and she said: "Yeah I can practice in front of her but she always, she, like, corrects me all the time and that depresses me." Her feeling about being corrected by her roommate seems to contrast to the reaction she had to her teacher's oral corrections: 
Ah... that's fine, I mean, because I take it as good criticism but, I do not know, he is really nice about it when he corrects you so, I do not take it personally or anything like that. So, I just try to remember what he says, so that I can do it right the next time.

Her perspective about her teacher's oral feedback can be seen as consistent with the one she had about his written feedback:

... I would say most of it [the feedback] was what I expected because where I made the mistakes was kind of where I had some confusion when I was writing it, but some parts, even though he gave us this like sheet, I didn't understand what he was saying, so I went to him and asked him to explain it better to me.

Factual information about Angela and the other primary informants are summarized in Table 1. 
Table 1

Informants' Profiles

\begin{tabular}{|c|c|c|c|c|c|c|}
\hline Name & Age & $\begin{array}{c}\text { Spanish } \\
\text { level }\end{array}$ & Major & $\begin{array}{c}\text { Year in } \\
\text { college }\end{array}$ & $\begin{array}{c}\text { Previous Experience with } \\
\text { Spanish }\end{array}$ & Objectives \\
\hline \hline Josh & 23 & $\begin{array}{c}\text { Spanish } \\
101\end{array}$ & Horticulture & Senior & $\begin{array}{c}\text { Visited Mexico and } \\
\text { Dominican Republic for } \\
\text { vacation }\end{array}$ & $\begin{array}{c}\text { To be able to gain } \\
\text { the respect of his } \\
\text { co-workers }\end{array}$ \\
\hline Anna & 20 & $\begin{array}{c}\text { Spanish } \\
101\end{array}$ & Psychology & Senior & $\begin{array}{c}\text { Studied for two years in high } \\
\text { school and has friends from } \\
\text { Colombia }\end{array}$ & $\begin{array}{c}\text { Complete a } \\
\text { requirement }\end{array}$ \\
\hline Yukiko & 30 & $\begin{array}{c}\text { Spanish } \\
101\end{array}$ & Fine Arts & Graduate & None & $\begin{array}{c}\text { Be able to } \\
\text { communicate }\end{array}$ \\
\hline Henry & 21 & $\begin{array}{c}\text { Spanish } \\
102\end{array}$ & Accounting & Senior & $\begin{array}{c}\text { Spanish 101 and two years in } \\
\text { high school }\end{array}$ & $\begin{array}{c}\text { To live in a } \\
\text { Spanish-speaking } \\
\text { area }\end{array}$ \\
\hline Laura & 51 & $\begin{array}{c}\text { Spanish } \\
102\end{array}$ & English & Senior & Spanish 101 in Summer I & $\begin{array}{c}\text { To have the basic } \\
\text { comprehension } \\
\text { level and } \\
\text { complete } 12 \\
\text { credits }\end{array}$ \\
\hline Angela & 21 & $\begin{array}{c}\text { Spanish } \\
102\end{array}$ & Communications & Senior & $\begin{array}{c}\text { Spanish 101 in Summer I and } \\
\text { in high school }\end{array}$ & $\begin{array}{c}\text { Complete a } \\
\text { requirement }\end{array}$ \\
\hline
\end{tabular}


Although, Josh, Anna, Yukiko, Henry, Laura and Angela were selected as primary informants, several other students were interviewed as well. Two of them--Julie in Spanish 101 and Mike in Spanish 102--also provided important insights for this study.

\section{Secondary informants}

\section{Julie}

Julie's dream was to be a college professor. Her major in Education required her to complete four years of Spanish. Besides that, she wished to be able to read, write, and speak well in Spanish. She wanted to study abroad and felt that Spanish would give her more choices of countries. Like most of her classmates, Julie had studied Spanish in high school. When I asked her about the experience, she said:

Not good. It was a class where you play cards in Spanish class, you do not do anything. I didn't learn hardly anything but compared to what I am doing now, I have an A, so I must have learned something.

Talking about her perspective about the class, she revealed a little about the students' behavior in the classroom:

The class... we do a lot of working together which is good but I think that half of the time we do not really do our work when we are working together.... We talk about what we are going to do on the weekend and so many other things... nobody really does that [the classroom activities]. Like the one we have to sign our names, you are supposed to go and ask the question and have a conversation, nobody does that really, we just go to anyone and say "sign this," you know, but I like the class, it is helpful, I am doing well...

Later she spoke about her own behavior in the class: 
You will see me watching the teacher, reading my book, doing my activities, you might see me talking about non-Spanish things, only once in a while, though because I like to pay attention in class. You will see me actively participating, honestly.

She considered vocabulary to be her strongest area in Spanish:

Because it is the easiest, it is just memorization. My worst area would have to be grammar and sentence structure, it is what I would be more likely to do bad in because in English we say things in a different order then they say in Spanish, so vocabulary would be the easiest.

Vocabulary played an important role in the process of writing her Spanish composition: Well, in my writing I tried to do a lot of things that weren't even in class because I didn't want to be so basic. So I looked up in the dictionary and I tried just to translate it and stick it in, but when you learn new words and you do not know them and you try to put them in a sentence I did not know what structure it should be in, so you know I think I lost too many points for that.

\section{Mike}

Mike's experience with Spanish in high school seemed to be similar to Julie's: "In high school I wasn't terribly serious about it, but at that point we had to pick a language so I picked Spanish.” At Regency, Mike was taking Spanish as a requirement for his major in computer engineering: "For my major I needed two cluster classes that were one after another, and Spanish was equivalent, or it was an accepted cluster class, and I have a little better background in it from high school, so I took it during the summer." But he said that he would also like to know Spanish in order to travel: "I am not really into 
traveling but I would like to go to Spain. I like Spain more than Mexico, just because, I do not know, Mexico is too close."

About his Spanish 102 class, he said: "Oh, I think it is a real good class, well more interesting than it was in high school, but it seems a little more serious." Mike talks about his behavior during the classes:

I take notes, when he told us not to take notes, because if I do not take notes, and I leave class, and I go straight to work, when I get there I forget what we talked about, so I take notes anyway, even though he told us not to. I learn a lot better if it is interactive, so I try to volunteer a lot, unless I have no idea what's going on, then I try to put my head down and be invisible.

Later he reveals his preoccupation with learning the verbs in Spanish:

Like, out of the class, especially with the verbs, I make, I get on the computer and make a grid and I try to learn that way. Like I made this to try to study the different verbs like I put the definition and then the different verb forms, I do a lot of just repeating to myself... sometimes I do not know which ones are the most used, so I try to memorize them all, and I end up sort of memorizing them but not quite.

Clearly, students' perspectives on their Spanish class were influenced by their goals and past encounters with language learning. Likewise, teachers' perspectives derived from their experiences as well. 


\section{The teachers}

\section{Carlos}

Carlos is a graduate student from a Spanish-speaking country in South America. Being a Graduate Teaching Assistant at Regency University gave him his first opportunity to teach Spanish in a classroom. In his home country, he supervised a computer lab, where once in a while he would tutor students in Spanish.

Teaching Spanish 102, he used a lot of games, visual aids and writing on the board to stimulate students to learn. Every time he would start a lesson, the first thing he would tell his students was "Cierren sus libros" [Close your books]. Besides having their books closed, he would also require that students not take notes in class. He wanted students to pay attention to him all the time, and he also appreciated their participation.

For him, teaching was also a chance to learn: "I like being in front of students. I learn from them--you won't believe it but I am also learning. I am learning the language because sometimes they ask me tough questions....I learn about their culture. I am also learning how to teach Spanish to Americans." Outside the classroom, though, Carlos did not like his job as well: "I like teaching, not correcting homework. That's the bad part about teaching and when it comes to grading, you know, it is tough." Interestingly he compared teaching with acting: "I like teaching because you are like an actor, but the difference is that in a theater the audience grades you, and here you grade them. They are after the grades, the audience."

Carlos explained that he disliked grading because he was always afraid of being unfair with his students. He worried that another teacher could have a different 
perspective from his: “... the way, for example, I read a composition to the way another teacher might interpret it is just different."

\section{Luisa}

Luisa came from Europe to pursue a Master's Degree in Foreign Languages. This was her third semester as a Graduate Teaching Assistant of Spanish at the University teaching Spanish 101. Even though she was a native speaker of Spanish, she said she liked teaching Spanish 101 because "they [the students] do not know anything and they want to try to speak... so it is easy because they do not know anything."

Like Carlos, she would frequently bring visual materials to the class, like a picture of the Simpson family to teach vocabulary related to family. In contrast to him, she would allow students to have their books open on their desks and take notes during the classes. Most of the time she would use different activities in order to entertain the students. These activities were each focused on skill development, such as listening, reading or speaking.

Luisa explained what she expected from students' compositions in their first semester of Spanish:

I mean they are in Spanish 1, you know, they can't do that much writing. So I really, I think I grade very high because I understand that it is difficult the first composition you do the first semester. And so if I see that they are talking about what I am asking, if they try to use all we use in class, that's a good composition for me.

Like Carlos, Luisa did not like grading or giving feedback on compositions. She explained: 
I do not really like grading compositions, it is slow and you have to give all this feedback, but hopefully they [the students] will appreciate it, but normally they do not really care that much, so I do not think it is worth it, the work you put in it and the work they pay you back.... It is not worth it I think.

Carlos and Luisa had things in common like teaching background, approaches for teaching, and perspectives about correcting compositions. These factors could have influenced the findings, suggesting a limitation to the study.

\section{Limitations of the study}

The fact that the teachers were aware that an investigation was being conducted in their classroom and that their feedback on the compositions would subsequently be analyzed might have affected the way they related to their students' writing. Moreover, I was concerned that students would be reluctant to talk candidly about their reactions, particularly if they were negative. Aware of these limitations, I emphasized to both teachers and students that this project was in no way an evaluation of their performance and that their names would be kept confidential. Additionally, it was explained to the students that their sincere views would contribute enormously to understanding of students' perceptions of teachers' feedback. It was also explained that their opinions would in no way affect their grades.

Based on the argument that a qualitative approach would be more suitable for this study, the research design and methodology have been explained in detail in this chapter. The chapter described the procedures for data collection and analyses as well as the time frame, setting, and participants for the study. The limitations of the study were also 
explained. The next chapter presents the findings of the investigation, focusing on students' perspectives of the teachers' written feedback on their compositions. 


\section{Chapter 3}

\section{Findings}

\section{Introduction}

"All the feedback was helpful," "[the feedback] was helpful and understandable," "I didn't find any aspect of the feedback not helpful," "[the feedback] was very helpful to me and I am glad I have a chance to make the corrections and get a better grade." On the surface, it seems that students' perceptions of their teachers' written feedback were positive. But if we delve into the data a bit deeper, we can see that their reaction is actually more complex, encompassing: 1) the importance of grades, 2) the tendency to equate feedback with grammatical correction, 3) the directness of that correction, 4) the initiative of the student to ask for help, and 5) the willingness of the student to accept the teachers' feedback. This chapter explores these categories in greater detail.

\section{The importance of grades}

Ah, I think that just all of it [the feedback] was helpful because my grade raised four percent after I did all my corrections, so I only got like two percent wrong, so agreement and word order helped me a lot and also like she scratched out the extra words that I didn't need and that helped a lot too.

When asked about the most important aspect of the teacher's feedback on her composition Anna seemed to be motivated by the fact that her grade improved after she made the corrections proposed by the teacher. This positive reaction which directly associated the improvement of the quality of the paper with the objective of getting a better grade was also seen on the questionnaires that were distributed to students in both classes. Another student in the class wrote: "She marked every error I had. This will 
allow me to correct everything in order to get a good grade." When asked if, based on her teachers' feedback on her draft, she would be able to write a good final paper, Julie said: "Yeah, I think I can do a good paper out of this, I already got a 92 so..." I asked Henry a similar question: "Do you expect to get one hundred percent on your final composition?" and his answer was: “Uhum... That's what I am shooting for but I won't expect it. I hope ah... as long as I improve on it, just a higher, a higher grade.” Likewise, Carol commented about the final composition "I am hoping I will get a good grade." Laura was another student that showed preoccupation with the grade: "I am concerned about the grades because it does pull your average down, I was really shocked that I got a D.”

Mike was one more student who expressed that the grade on the composition was a priority and also suggested that interpreting the teacher's comments might not always be an easy task:

I mean it does not affect my grade a whole lot, uhm maybe he could have used, well let's say used English to explain it to us because when we had to interpret his comments sometimes it makes it harder for us to... for me to... to do it, because I have to interpret what I did like, what is wrong and interpret his notes on what I did wrong.

Trying to make sure I understood one of his answers on the questionnaire, I asked Mike if he still thought, as he had stated before, that his teacher should have been a little more "lenient" on the feedback, since it was his second semester studying Spanish. His answer was: "Well, no, I thought when I wrote that, but I got a 90\% on the final [draft] so...." Thus, Mike was critical of his teacher's feedback until he learned that his grade on the 
composition was a good one; based on the teacher's evaluation of his performance, he seemed to revise his evaluation of the teacher's feedback.

Studies like Dohrer (1991) and McGee (1999) have already revealed that students revise their texts thinking about the teacher's response. They suggest that the changes students make are superficial and based on the teachers' comments with the objective of getting a better grade on the course.

Most students said that the grading criteria given by the teacher, which had explanations for each grade range, was very helpful for them to understand the grades they received. Henry explained: "He [the teacher] gave us a grade, so it tells us what classification we fall in the criteria. It was in the syllabus like telling us what he wants to look for, and he just attached the grade like on the scale he gave us."

Henry seemed to equate grade and grammar corrections. After our long talk about grammar and verbs, I asked him: "Do you think your teacher gave too much emphasis for grammar on the feedback?" and the answer was: "Too much? No... I set words in the wrong places but he didn't take a whole lot of points for it but he just made sure I knew how to change it and stuff like that."

As for the content and organization of the composition, I observed that the references made by the teachers with this regard were mainly comments like "Buen contenido y organización" [Good content and organization] at the end of the page or the grades students received for each of these categories. This lack of complexity during the revision process and grade-driven motivation is consistent with Dohrer (1991): Although students claimed they understood the purpose of the teachers' comments, they quickly abandoned the goal of improving their own writing skills 
for the more immediate goal of getting a higher grade. The teachers' grading practices seemed to reinforce this pragmatic view of revision, because students did indeed receive a higher grade on their revisions, despite their superficiality. (p. 51)

Students' perception of a better paper and consequently of a better grade was based in general on grammatical changes they were asked to make by their teachers. Answers to the question "What aspect of the feedback was the most helpful for you?" were unanimous: "Grammar."

\section{The importance of grammatical accuracy}

Flavia: The feedback you said in the questionnaire was what you expected. You said: "She corrected everything."

Josh: She corrected everything.

Flavia: And what was the most helpful thing she did?

Josh: Ah, I would say grammar, like I used "sacar," "to take," you know, in several different places where I knew "sacar" meant "I want to take pictures," and "tomar" goes along to take other things, take a course, a class, so she corrected a lot. So I would say grammar, the grammar corrections because I can just go right back, and it is very easy to write the second draft. I probably spent twice as long writing the first draft because for the second one the corrections were so good. Josh only mentioned grammar when talking about the positive aspects of the feedback, and when talking about grammar he only mentioned his problems with the verbs. Anna's declaration, too, seemed to fall in the same category and revealed what 
most students expressed in the interviews and questionnaires about what they perceived to be the most helpful aspect of the feedback:

I did pretty well on vocabulary but grammar was the one I had most problems with, so she helped me a lot more with grammar... I had problems with the verbs... also agreement and word order it helped me a lot because in Spanish it is different.

Luisa, the teacher in the Spanish 101 class said during the interview that "it is very common to find mistakes in grammar, so I think it helps when you correct grammar... the verbs, it is really hard for them to get the infinitive or conjugate it, because they do not have it in English, so it is difficult for them."

I asked Mike, another student in the Spanish 101 class, "What could the teacher have done to help you more with your composition?" and he answered:

Maybe be a bit more specific, like, well if you are using a verb it is pretty obvious which verb you have to use depending on what you are talking about. But like prepositions, that's what I had. I had a lot of preposition problems so maybe he could have been--because those are kinds of things that depends on usage so maybe he could have told us which preposition would be more correct.

In the Spanish 102 class the second composition required that students use the verbs "ser" and "estar" [to be], and most students expressed that they had difficulties using these verbs properly. Even after the teacher's correction, they were still in doubt about which verb to use. When asked what the most helpful thing his teacher had done in order to help him write a better final paper, Henry answered: "Just tell us which to put 'ser' or 'estar.' I think I just put some words in it that I needed to take out, but using the 
wrong form of the verb was the biggest problem." Further he attested that "Even though he [the teacher] put which 'ser' or 'estar' to use, I am still not sure on, like, why to use that one, like when to use each one, so I guess we could have gone over that."

On the questionnaire, Laura put that the most helpful aspect of the feedback was "spelling." In the interview I asked her if that was still her opinion and she said: "Not so much. I have to say more grammar, not necessarily word order but I tend to use the wrong verb tense."

For Yukiko the grammatical terminology used in the feedback was familiar because she had studied English as a foreign language before starting Spanish. But in her opinion American students might have problems understanding some of the words used by the teachers in the feedback:

When you learn English you have that kind of stuff, you know... I know that kind of coding. So it is not difficult for me but for other students, who is a native English speaker I do not know if they have that kind of experience... If they do not understand agreement, vocabulary yeah that may be, but expressions like 'word order,' I am pretty sure they have problems with that, but like I said, as a foreign student, I already know that kind of stuff.

Confirmation for Yukiko's hypothesis is found in Josh's statement. When I asked him if he knew what "agreement" meant he said: "I am guessing agreement, she is just talking about like 'muchos personas' [a lot of people], it is supposed to be 'muchas personas' that's what I am assuming she means." Even though he was right, he seemed to be unsure of the meaning of some of the terms used in the feedback. 
It is important to make a contrast between what students perceived as difficult during the writing process and what was considered by them not to be an obstacle. In spite of the relevance they gave to the grammatical aspect of the composition, other categories like the content of the text seemed not to be a concern. Students had some time of their class reserved for brainstorming with their classmates about what ideas they were going to include in their compositions. Anna, when talking about the content of the composition, said: “... before we wrote the paper we went over her [the teacher's] outline in class and I used everybody else's ideas along with mine, so I didn't have a problem with not having anything to write." Laura had a similar perspective in relation to the content of the composition: "Yeah, actually to think of what to write, I would know what to write, but I wouldn't know the proper verb endings sometimes--how to say the word that I was trying to say."

When writing the composition it seemed that the biggest problem for students was related to the grammatical part of the language and consequently that is what they perceived as the most helpful aspect of their teachers' written feedback on their compositions. The teachers in the two groups used a similar strategy for giving feedback on grammar and on some other categories: they used indirect feedback to make students aware of their mistakes without showing them what the correct answer was. Students expressed different reactions to this approach.

\section{Direct versus indirect feedback}

Yeah, when he just underlined it, that meant nothing to me, because I didn't know what I did wrong in the first place or I wouldn't have done it wrong. And then a line under it just really does not tell me anything.... Yes, he underlines it and that 
means pronoun but I didn't understand what he meant by pronoun. He could have wrote out here like you have to say "her" and not "she" or something like that. I know he probably does not have time but...

Angela was just one of the students who expressed her dislike for "indirect feedback" (Ferris and Roberts, 2001) which was used by both teachers. According to Ferris and Roberts "indirect feedback occurs when the teacher indicates in some way that an error exists but does not provide the correction, thus letting the writer know that there is a problem but leaving it to the student to solve it" (p. 163).

Similar to what happened to Angela was the experience Yukiko had with indirect feedback:

Yeah `cause when he says spelling, I am not really sure ah... like, I look in the back of the dictionary and that's how you spell--but I do not really know how to spell it, you know what I mean? Or if it is conjugated wrong in a certain spot--you know how "tengo" [I have] changes to "tiene" [you have]. You know what I mean like that? I wasn't really sure exactly what he meant with some of those things, so I was going to ask him about that.

The teachers both had a "Guía para la composición" [Guide to the composition] (see Appendix H), which they had created independently of their GTA training. It contained the codes, symbols and abbreviations they used to give feedback. Two other sheets entitled "Tipo de errores" [Types of errors] (see Appendix G) in Spanish and a "Correction chart" (see Appendix I) in English were also given to the students by the teachers to help them understand the marks on their papers. In contrast to the philosophy of process writing espoused by the program, all the symbols in these teacher-designed 
sheets were related to aspects like grammar, agreement, vocabulary, spelling and word order. None of them made reference to the content or organization of the composition. Such importance seems to have been given to indirect feedback by the teachers that their main strategy when giving feedback was using the symbols and codes of the legend they handed out to make students aware of their problems. Henry stated how important it was for him to have the legend: "He gave us this extra sheet telling us what these proofreading things are, I mean I do not know some of the English proofreading symbols and stuff like that, so he made us the symbols and made us a sheet telling us what each symbol is. So now I can go back." About the legend Angela said, "If I wouldn't have this, I would have no idea what he was talking about, because when he just underlined, if I didn't understand it in the first place, and I got it wrong in the first place, then I wouldn't understand it the second time around anyway." Another student also found it important to have the legend: "The legend that she handed out was helpful because I can look that up and see exactly what she means, and she is pretty specific about what I did wrong, so it is pretty easy."

In an interview Mike explained his frustration with indirect feedback:

When I took Spanish 1, my teacher was a lot more specific than now with word usage, and here he talks about subjects, verbs, agreement and he is a lot more general, so I was just hoping for a lot more specific as to, like, I used the wrong preposition. Well, I tried another preposition and it was still wrong I wasn't sure which one to use so I just put another one in there that I thought I had heard before, but it didn't work... 
Earlier he had already expressed his problems with this type of feedback: "I believe he [the teacher] is trying to tell me that certain prepositions are being misused, but I am unsure as to what else I should use in its place." Hyland and Hyland (2001) confirm the problems indirect feedback can cause: "Indirectness... can open the door to misinterpretation" (p. 207).

Another student in the Spanish 101 class, Julie, explained why she perceived this kind of feedback to be unhelpful for her during the process of revision:

I think that's hard because that way I get confused, and the process of researching what the right answer is, it is a little bit confusing in my opinion. I did it wrong first time just give me the right answer... When you are researching you see all these words that mean a bunch of different things, I definitely prefer her to write it down for me... I wanted it to be corrected for me. See, what I am going to do is, these sentences that she put like "I cannot understand?" I am just going to take them out because I do not know how to say--I tried my best to say them right on the first time, and they obviously weren't right, so I am not going to try.... It only has to be 300 words so I can take those out. This is a lot of work for Spanish 1, you know, a composition... so she should tell me what the right thing is, and it is less work for me, if she tells me.

Later she added:

Because learning a foreign language is as difficult as it is, it is really a lot to grade, especially in the Summer session, which does not bother me because I can keep up with it, but it is a lot to remember and a lot to put together in a short period of time and to go back and look up all those individual things takes a lot of 
time too. I know I would learn better if it was just given to me the right way, and I can just study it you know, because at this fast pace, there is really no time to go look it all up, you know what I mean? Like, to write a composition anyway I had to look up a bunch of stuff just to get it all done on paper. To go back and do it all over again seems a waste for me.

In spite of the negative aspects commented on some informants, others like Anna expressed their positive attitude for indirect feedback: "Yeah, because I need to learn on my own how to correct the mistakes, so it pushes me to really know what to do for the rough draft, so that I will learn for the final draft." Despite her positive attitude toward indirect feedback, Anna also ran into difficulties with this approach:

...the only problems I had was with the verbs and on my final paper. That's the only thing, like, I knew it was supposed to be corrected, but I did not know what to put in the place of it, so I just left it the same. That's why I think I got it wrong on my final draft.

Other students also had a positive view in relation to indirect feedback. A Spanish 101 student gave her opinion on why it was helpful:

I think that if she puts something like that, and I have to go in the book and look it up, I would probably learn it more instead. If she just writes it, I wouldn't take very much effort to write the paper. So now, I have to go up and look that in the book and figure out what I did wrong.

Amy's declaration explains the technique from a students' perspective and also illustrates the positive reaction: 
In Spanish 1 it was just corrected for you. You retype it and you turn it in. This time he [the teacher]--some of it he corrected but he always labeled his corrections as to why it was wrong whether it was gender, sub-verb, prepositions, so he told me how I was wrong, so I could correct it based on the--OK, this is the wrong preposition, which preposition do I need? So that made myself think, so it wasn't just "correct it and retype" and I actually had to think and redo.

Earlier in the interview she had explained why she liked indirect feedback:

I like how he grades on the compositions because he will actually say what is wrong and then it is up to me to fix it, instead of it just being corrected and then you just fix it and you turn it in, so it still makes you think, even when you are doing your final draft, which I like.

Consistent with the same idea, another student said: "It was not his job to tell me exactly what is wrong and how to correct it. That's what I'm supposed to be learning in the class." Another student wrote on the questionnaire: "Thank you for teaching instead of just correcting."

Regardless of the students' opinions, the teachers seemed consistent in their use of this type of feedback. Carlos, the teacher in the Spanish 102 group explained his strategy in an interview:

I want them to realize what their mistakes are in the first draft. I do not correct anything. I just tell them "Hey, you need to change this or you need to use this"... When I say I do not correct, if they write something wrong, I do not scratch it, and I don't say this is the correct word because it is their job to find out what their mistake is. 
The other teacher, Luisa, shared the same belief: “... they need to find it. I just give them what is the problem if it is in spelling, if it is in grammar, if it is word order, but they need to find how to correct it."

Some students though, could not, from the indirect feedback symbols, figure out what the teacher meant or could not, by themselves, find the correct answers. In order to clarify misunderstandings of this sort on the feedback, most students agreed that the best way was to talk to the teacher, whether it was during the teacher's office hours, after class, or even during the class.

\section{Student-initiated feedback}

...the corrections he made on my paper actually didn't make sense to me but then when I went to talk to him, I understood...just when I went to talk to him, he was more clear and he gave me examples that I was looking for and tips.

Angela felt that it was extremely important to talk to her teacher about the feedback she received on her composition and so did Yukiko, who expressed that talking to the teacher about the feedback was very important not only for her but for all the students:

Flavia: So did you talk to her [the teacher] after that? Did you go to her office hours?

Yukiko: No, she gave me this [the composition] and I looked through and I said "so do you mean like this and that?" And she said "yes."

Flavia: In class?

Yukiko: Yeah, in the class. OK, then that looks easy. So, my session was that. So if every student could have that kind of session, go through and say 'I don't 
understand that, you know, just take a couple of minutes or whatever to go through with students maybe that would be easier because everybody has different problems... She [the teacher] should talk to the individual even for a short period of time. She could pinpoint what the problem is.

This need was felt not only by the students, who looked for their teachers before, during, or after the classes and during their office hours, but also by the teachers, who seemed to expect to meet with students for clarification of their feedback: "If they do not understand, if they do not know, they ask for help" Carlos said. Luisa confirmed that students would come to talk to her about the feedback to clarify their doubts: "When I give feedback they come to see me and they say things like 'Oh I tried to say that,' 'How can I say that?' In her opinion, meeting with students complements the written feedback she gives: “...if they don't get it, they ask me.”

Sometimes just the potential of misunderstanding prompted students to seek clarification, as was Mike's case: "He clearly pointed out which words needed more work, but I don't feel like I am up to the comprehension level needed to understand fully his remarks." Another student said that she asked for the teacher's help during the class: "I asked her some things in class the other day--just simple, simple things, like I couldn't read her writing. I didn't really know what she was saying, and things like that, so I already made sure I understood everything." Henry was one more student that solved his questions by talking to the teacher. He also emphasized the advantage of asking for clarification in English: "I asked him, I went up to him and wanted to make sure what his writing was saying down here because I had trouble translating that, but he told me...once I asked him and he told me in English, it was OK." 
The students who chose to ask for additional feedback said that it made all the difference for them, helping them not only understand some unclear aspects but also changing their whole impression of their teachers' work. Laura said: "Well the only reason I found this out is because I went after class to his office and otherwise it was just underlined or circled and the different abbreviations were there." When I asked Josh about one thing that would have helped him understand the feedback better, he said: "Well, she should have gotten really involved and have us come up to her office upstairs and talk about our compositions. She could have done that but she didn't have to do it. I think she did a great job."

Most students, however, did not go talk to the teacher during his/her office hours about the feedback, although they had no doubt that by talking to the teacher, things could have been better understood or clarified. Josh said: "What I should have done for like two sentences she wrote "No entiendo" [I do not understand] and so what I should have done was gone and talked to her about what I was trying to say, and she could tell me how to say it, but I never did that." Anna had a similar feeling about not going to talk to the teacher:

I pretty much knew what everything meant, but something that I just didn't know how to fix and I didn't have a chance to ask her before I turned it in, that's why I got it wrong on the final, of course.... If I would have asked her, she would have helped me correct it.

One of the teachers, Carlos, said that even though he made it clear in the class that he was available to talk to the students about their compositions during his office hours, very few went to talk to him, “They do not come," he said. In his opinion, talking to 
students is very important for the understanding between teachers and students: "I would like to go one by one asking 'What do you want to say? What do you mean?' "

The opportunity to talk with the students seemed to have such relevance that the correction chart used by the teachers to give feedback had, as one of the codes, "see me" which meant "see me before or after the next class meeting" and a similar one was a quotation mark that meant "I don't know what you are trying to say; rewrite or ask me."

In sum, when some aspects of the feedback they received were not clear, some students found that the best alternative was talking to their teacher. The data reveal that the conversation between teachers and students seemed to be crucial for their understanding and clarification of problems related to the teachers' written feedback. Teachers had their office hours available to talk to the students about their compositions, although some students chose simply to talk to the teacher after the class and others even asked their questions during class. These dialogues were to clarify aspects of the feedback that students had problems understanding. They were not to challenge the instructor's suggestions. The teacher's authority on matters of feedback was rarely called into question.

\section{Acceptance of the teachers' authority}

Why this word and not that one? I do not know why but she didn't like it. She crossed it off, so I changed it, but I still do not understand why I cannot use this word...

Yukiko seemed always to want to know "Why." One of the items on the questionnaire asked what students would tell their teachers if they could go talk to them about the feedback they gave, and she answered: "I would need an explanation for all the 
feedback, all the corrections she made. That makes it clear. Then I do not have to make the same mistakes again." And in the interview she explained her answer:

So, yeah... I wanted her to explain like the parts she just crossed out and then gave me the answer you know I want to know why she has to cross this out and then why that's the word I need to use instead of the word I used. You know, this kind of stuff I really need to know.

Besides her desire for explanations clarifying the feedback, she expressed the need to have more "encouraging feedback" from the teacher during the writing process. The fact that her teacher just wrote "Muy bien" [Very good] at the end of her composition made her uncomfortable. In her opinion adults still need some rewarding comments and incentive when learning a new language. She said: “The teacher just said 'Muy bien' so she isn't giving me that much comments, so I wish I could have something like 'Oh, this sounds beautiful' or 'This does not sound very natural,' you know, stuff like that." She commented that one of her classmate's compositions had a lot more comments than hers. In her opinion, the difference in feedback might have been because this other composition "touched" the teacher more, and the teacher was more interested in helping this other student. She also said that if the composition does not say much to the teacher, he/she does not write many comments or only writes one small final comment in the end, like the one she received.

Even though Yukiko expressed discontentment with the feedback in general, she was one among the many students who accepted the teacher's suggestions in the feedback: "Oh yeah, I only worked on the stuff she changed." Josh echoed the same 
thought: "Yeah I just worked on the changes... I pretty much copied word for word." Anna was one more of them:

I think she [the teacher] did pretty well. She is very organized, and she is very thorough. She made sure she corrected all the mistakes on the paper because I do not think I got anything wrong on my final paper that wasn't already marked on the other paper... I pretty much just made the changes that she made, the corrections that she asked me to make....

As presented earlier, Anna's positive view of the feedback was related to the grade she received from her teacher: “Ah, I think that just all of it [the feedback] was helpful because my grade raised four percent after I did all my corrections...." Henry even showed admiration for his teacher and contemplated the fact that the changes made were as the teacher wished:

I've had teachers before when they proofread your papers, they just look over briefly, and they won't correct everything, and they just leave it up to you to do it again. I mean he [his teacher] went over the whole paper and made all the changes he thought should be made.... I think he did a pretty good job.

Another student declared how important the teacher's opinion was for her: I was appreciative of the positive feedback I received on my paper. When I saw all of the red ink on my paper, I was very worried, but when I saw that the instructor said that I did a good job and that the paper just needed a little more work, I felt a lot better about my performance.

Some students equated the teacher's feedback with corrections: "He [the teacher] went through the composition, marked all the mistakes, and wrote what type of mistake it 
was." Another one said: "He told me the areas I needed to correct. I think it was needed for me to improve my paper." One more expressed his idea of a good feedback based on the teachers' corrections: "I found the feedback very good. It covered all aspects of what needed to be corrected." Similarly, feedback and corrections were linked in another student's mind: "I was expecting to receive the grade I did, plus he informed me of my mistakes."

Students' attitude of just working on the changes proposed by the teacher has been reported in Cavalcanti and Cohen (1993): "Learners may make changes according to what they think the teachers values are, out of a belief that the teacher knows best" ( $\mathrm{p}$. 84). Certainly the majority of participants in this study seemed to acquiesce to the teacher's suggestions without concern for text ownership.

Josh, however, was one of the few informants to question the teachers' authority to give feedback in the first place on compositions: "I do not know if she [the teacher] had the proper training for that." Nonetheless, he was very satisfied with his teacher's feedback and did not hesitate to say "I think she did a great job." Later he explained how he thought his teacher graded the compositions:

She probably only goes by two or three of these [compositions] and uses the other ones as some kind of standard way that she does not even understand exactly what they mean by "language" and one of these [definitions], you know, so I think she probably focuses on one thing, sees how she feels about the whole paper and sort of adjusts to the grades... She reads everything and then sort of says 'Is this a good paper? Yeah, it was pretty good' and probably compares it a little bit to the 
other students. I do not know how, I do not know what she had been studying. I do not know if she studied a lot of English or reading or Spanish I do not know... Consonant with his skeptical attitude, he also manifested his non-acceptance of the teacher authority when he challenged the teacher's expectation that students use the vocabulary taught in class or the vocabulary that was in the book: "I would like to find other words and be able to use words that I feel like using."

Similarly, Laura liked her teacher's feedback (“He was very good at explaining”) but also said that for her it was more important to have a story that made sense to her than it was just to accept what the teacher suggested for the content of the composition: "I mean the way he corrected it I could just have used his corrections, but to me it didn't fit the story." Later she added: "I hoped that from his corrections I had done it the right way, but I really wanted to finish, have a story that made sense, that each sentence followed the next." Laura chose not to accept some of the teachers' suggestions to change the content of her story and worked on the other aspects proposed by the teacher, expecting to have his approval. In retrospect, she valued her teachers' feedback and knowledge: "When I first got it back and everything was underlined and I felt like "what is the point? Why should I even turn another one in?' But in the long run it was necessary and the person that I have now for Spanish 200 does not really go over that as much as Carlos did and I can see the difference of not knowing like, what's wrong...." Laura said that she liked the fact that her teacher wrote comments next to her paragraphs along the paper, and that is what Yukiko and Angela expected their teachers to do also. Angela expressed it this way: "I think it would have been a lot more helpful if he would have wrote out on 
the side what he meant, but I understand that he has to grade a lot all the time for all of them, but just certain things that were unclear to me."

Despite some negative perspectives about the teachers' feedback, the willingness of students to grant the teacher the responsibility of fair assessment and the fact that they passively made the changes they were asked to on their compositions shows that there is a general acceptance from the part of the students of their teachers' authority when giving feedback.

The general positive attitude most students had about their teacher's feedback on their compositions, is composed in itself of different perspectives and expectations students had about the whole process of writing the composition. Issues like grades and the pervasiveness of grammatical accuracy had a fundamental influence on students' behavior in relation to the process. For the most part, the teachers seemed to meet the students' expectations with regard to feedback and evaluation, which led the students to have a positive perspective on their teacher's written feedback and also to accept their authority. The next chapter discusses the interrelatedness of these findings in light of a process model of teaching writing skills and raises questions for further consideration about the challenges of truly shifting away from a product orientation. 


\section{Chapter 4}

\section{$\underline{\text { Discussion and Conclusion }}$}

\section{Discussion}

In response to the question "How do adult beginning Spanish students perceive their teacher's written feedback on their compositions?" the data have revealed five interrelated factors contributing to students' reactions.

- $\quad$ The importance of grades: Students in this study seemed to have revised their texts with an eye toward which changes would help increase their grade. The importance of grades seemed to overshadow, for most students, any aspirations of improving their writing skills or the quality of their texts.

- The importance of grammatical accuracy: The "correct" grammar was pursued by students as the main objective of writing their compositions. Grammar correction was also the central feature of the teachers' feedback, despite the use of evaluation criteria that encompassed other aspects of writing as well.

- Direct versus indirect feedback: The techniques used by the teachers to give written feedback caused differing reactions among students who expressed their reasons for preferring either direct or indirect feedback.

- Student-initiated feedback: In order to solve problems encountered during the interpretation of their teachers' comments on their papers, most students in this study believed the best solution to be to talk directly to their teachers, whether or not they actually did so.

- $\quad$ Acceptance of the teachers' authority: Rare was the student who questioned his/her teacher's authority to give feedback on the compositions. Almost all 
the participants in this investigation blindly made the corrections on their papers in order to satisfy the teacher whom they expected to evaluate their final draft more positively. When their grade met with their approval, most students felt that the teacher's feedback had been effective.

The overwhelming emphasis on linguistic form over idea development and organization by both teachers and students in this investigation calls into question whether the composition activity really achieved the goal of improving students' writing skills, as it was intended to do. This chapter focuses on the implications of these findings in light of the theory of process writing.

\section{What happened to the writing process?}

In the Spanish classes investigated, writing is one of the four skills listed in the syllabus objectives that students were expected to develop during the course. Teachers received extensive training in the theory and application of the "writing-as-process" model. According to Gardner (1996), the process of writing is characterized by four stages: brainstorming and organizing ideas, writing the first draft, revising the content and organization of the draft and editing the mechanical aspects of the text.

The composition activities used in the Spanish 101 and 102 classes in this investigation were designed to include each of these stages. For the exploring and planning stage, the teachers reserved some class time for students to brainstorm and organize their ideas. Students then completed the drafting stage at home. Because students turned in drafts of their composition, the opportunity for revision, as well as editing and proofreading, was also provided. Moreover, the evaluation criteria 
corresponded to this model by including "content, focus, and structure" (Gardner, 1996, p. 233) in the assessment of the students' work.

The findings of this study indicate, however, that there was a breakdown of the process in the revision stage. As Gardner (1996) notes,

revision means much more than correcting grammar, spelling, punctuation, and mechanics. It involves a whole process of "re-vision"-rethinking and reshaping the content and structure of a draft to improve it at all levels: whole essay, paragraph, sentence, and word. To revise an essay, a writer adds, deletes, rearranges, and rewords material. (p. 245)

Sebranek, Meyer, and Kempner (1996) offer questions to help students with revision which further underscore the importance of the "whole essay" in this process: "Is the content interesting and worth sharing? Is the style natural and effective in getting my message across? Are there any major gaps or soft spots in my writing? How can I improve what I have done so far?" (p. 30). Looking at the students' compositions in this study and their teachers' comments, it is hard to believe that any of these questions were considered by either group. In fact, sentence and word-level mechanics--the "editing and proofreading" stage--seemed to dominate the whole writing process in the case of the classes investigated, shifting the emphasis from process to product. Furthermore, the teachers' preoccupation with linguistic accuracy transformed a writing activity into a grammar exercise, which actually pleased the students, who perceived grammar to be the most important part of their writing. In short, for teachers and students alike, the goal appeared to be to obtain a correct final copy rather than to refine the ideas communicated. 
While both the teachers and the students seemed to be satisfied with this "simplification" of the writing process, Choi (1991) warns that "mastery of mechanical and grammatical correctness [alone] will not suffice the requirements of good writing" (p. 446) and that "the decline of writing ability" may be due in part to this type of "preoccupation with the skills of grammatical analysis rather than the skills of composing" (p. 438). For most of the students in this study, however, prioritizing the value that their teachers placed on accuracy was an easy way to achieve their pragmatic desire for a good grade. It also left their relative indifference with regard to text ownership and the improvement of their writing skills comfortably unchallenged.

\section{Conclusion}

This study portrayed a reality encountered in two Spanish-as-a-foreign-language classrooms regarding the writing of compositions--a reality expressed in students' own words. What was initially intended as a way of helping students improve their writing skills took a different direction as the teachers applied the theory of "writing-as-process." The writing process was designed to have all its steps followed, but as the data in this study showed, the primary step for the students' growth as writers--the revision stage-did not happen. Apparently this reduction of the writing process was the result of teachers' and students' preoccupation with perfect grammar, which diverted their attention from the other aspects of the text. Moreover, the improvement of grades was the students' main goal, which was normally achieved by fixing their texts based on their teacher's superficial feedback.

What could teachers have done to motivate students search for ways to improve content and organization of their texts? What role might in-class activities play in shifting 
the focus toward greater balance of the four stages of composing? What additional factors may be contributing to the tendency among both teachers and students to focus exclusively on linguistic accuracy (students' level, students' motives, teachers' time constraints, etc.)? Such questions are beyond the scope of the present study. However we must continue to seek such answers if we hope to understand fully the complex issue of teachers' written feedback to students on their writing. 


\section{Works cited}

Amores, M. J. (1997). A new perspective on peer editing. Foreign Language Annals, 30, 513-522.

Cavalcanti, M. C., \& Cohen A. D. (1993). Feedback on composition: A case study of a remedial sixth-grader. Ilha do deserto 29, 83-98.

Choi, U. (1991). Writing process and the EFL writing. Language Research, 27, 437448.

Cohen, A. D. (1987). Studying learner strategies: Feedback on compositions. PASAA: A Journal of language teaching and learning in Thailand 17, 2, 29-38.

Conrad, S. M., \& Goldstein, L. M. (1999). ESL student revision after teacher-written comments: Text, contexts, and individuals. Journal of Second Language Writing, $8,2,147-179$.

Dohrer, G. (1991). Do teachers' comments on students' papers help? College Teaching, $39,2,48-54$.

Ferris, D., \& Roberts, B. (2001). Error feedback in L2 writing classes. How explicit does it need to be? Journal of Second Language Writing, 10, 161-184.

Gardner, P. S. (1996). New Directions. New York: St. Martin's Press.

Giberson, G. A. (2002). Process intervention: Teacher response and student writing. TETYC 29, 411-417.

Hyland, F. (2000). ESL writers and feedback: Giving more autonomy to students. Language Teaching Research 4, 1, 33-54.

Hyland, F., \& Hyland, K. (2001). Sugaring the pill. Praise and criticism in written feedback. Journal of Second Language Writing, 10, 185-212. 
Kepner, C. G. (1991). An experiment in the relationship of types of written feedback to the development of second-language writing skills. Modern Language Journal, 75, 305-313.

Lalande, J. F. (1982). Reducing compositions errors: An experiment. Modern Language Journal, 66, 140-149.

Lamberg, W. J. (1977). Practices and attitudes in providing information on writing performance. University of Texas, Austin. (ERIC Document Reproduction Service No. ED 158 276)

Lehr, F. (1995). Revision in the writing process. ERIC Clearinghouse on Reading, English, and Communication, Bloomington, IN. (ERIC Document Reproduction Service No. ED 379 664)

Long, S. S. (1992). Using the process-model for writing options for responding to student drafts. Paper presented at the annual meeting of the American Association of Teachers of Spanish and Portuguese ( $74^{\text {th }}$, Cancun, Mexico, August 9-13, 1992). (ERIC Document Reproduction Service No. ED 352 826)

Marshall, C., \& Rossman, G. B. (1999). Designing qualitative research. Thousand Oaks, CA: Sage.

McGee, S. (1999). A qualitative study of student response to teacher-written comments. Unpublished doctoral thesis, Purdue University, West Lafayette, IN.

Paulus, T. M. (1999). The effect of peer and teacher feedback on student writing. Journal of Second Language Writing, 8, 265-289.

Richardson, S. (2000). Students' conditioned response to teachers' response. Portfolio proponents, take notes! Assessing Writing, 7, 117-141. 
Sebranek, P., Meyer, V. \& Kempner, D. (1996). Writers INC. Massachusetts: D.C. Heath and Company.

Veerman, N. O. (1999). Adult student reaction to teacher response. Unpublished doctoral thesis, University of Central Florida, Orlando, FL.

Walvoord, B. E. F. (1986). Helping students write well. New York: Modern Language Association.

Zinsser, W. (1988). Writing to learn. New York: Harper \& Row. 
Appendix A

\section{Grading Criteria}




\section{Grading Criteria for Compositions}

Content (Information Conveyed)

- minimal information; information lacks substance (superficial); inappropriate or irrelevant information; or not enough information to evaluate.

Points

$15-18$

$19-22$

limited information; ideas present but not developed; lack of supporting detail or evidence.

$23 \cdot 26$

adequate information; some development of ideas; some ideas lack supporting detail or evidence.

$27-30$

very complete information; no more can be said; thorough, relevant, on target.

Organization

series of separate sentences with no transitions; disconnected ideas; no apparent order to the

content; or not enough to evaluate.

- linited order to the content; lacks logical sequencing of ideas; ineffective ordering; very choppy, disjointed.

an apparent order to the content is intended; somewhat choppy, loosely organized but main poinls do stand out although sequencing of ideas is not complete.

$20-22$

logically and effectively ordered from introduction to conclusion; main points and details are connected; fuent

Vocabulary

- inadequate, sepetitive, incorrect use or non use of words studied; literal translations;

abundance of invented words or words in English; or not enough to evaluate.

$12-15$

erroneous word use or choice leads to confused or obscured meaning; some literal translations and invented words; limited use of words studied

$16-19$

adequate but not inpressive; some erroneous word usage or choice, but meaning is not confused or obscured; some use or words studied.

$20-22$

broad; impressive, precise and effective word use/choice; extensive use or words studied.

$23-25$

Language

- abundance of errors in use and form of the grammar presented in lesson; frequent errors in subject/verb agreement; non-Spanish sentence structurt; crroneous use of language makes the work mostly incomprehensible; no evidence of having cdiled the work for language; or not enough to evaluate.

frequent enrors in use and form of the grammar presented in lesson; some crrors in subject/verb agreement; some errors in noun/adjective agreement; crroneous use of language often impedes comprehensibility; work was poorly edited for language.

occasional errors in use and form of the grammar presented in lesson; occasional errors in subjoct/verb or noun/adjective agreement; erroneous use of language does not impede comprehensibility, some editing for language evident but not complete.

no errors in the grammar presented in lesson; very few crors in subjec/verb or noum/adjective agreenent; work was well edited for language. 
Appendix B

Demographic Questionnaire 


\section{Background Information Questionnaire}

Name:

Current address:

E-mail address:

Current phone number:

Gender: $\quad$ Male ___ Female:

Age:

Year in college: Freshman Sophomore Junior Senior other

Major at WVU: Minor (if applicable):

What country are you from?

What is your native language?

Have you studied Spanish before taking this class? If yes, please explain.

Have you ever been to a Spanish speaking country? If so, which one? For what reasons?

What goals do you have for learning Spanish?

Do you use Spanish outside the classroom? If so, in what ways?

How long do you intend to keep studying Spanish?

Do you know any other languages besides Spanish and English? If so, which one(s)?

Would you like to study other languages? If so, which one(s)? 
Appendix C

Interview \#1 with Students 
$\underline{\text { Interview \#1 with students }}$

\section{Sample questions}

- $\quad$ Tell me about your Spanish class.

- $\quad$ If I were a fly on the wall, what kind of things would I see you doing in class?

- What is it like when the teacher makes corrections in the class?

- $\quad$ How do you feel when it happens? 
Appendix D

Interview \#2 with Students 
Interview \#2 with students

\section{Sample questions}

- Was the teacher feedback what you expected?

- What types of comments were most helpful?

- What aspects of the feedback were least helpful?

- $\quad$ If you could give your teacher feedback on his/her feedback, what would you say? 
Appendix E

Questionnaire 


\section{Questionnaire}

Name:

1. Was the teacher feedback what you expected?

2. What types of comments were most helpful?

3. What aspects of the feedback were least helpful?

4. If you could give your teacher feedback on his/her feedback, what would you say? 
Appendix F

Interview with Teachers 


\section{Interview with teachers}

\section{Sample questions}

- What do you like best about teaching Spanish?

- What do you like least about teaching Spanish?

- $\quad$ How do you go about grading compositions?

- What do you focus on first?

- What kinds of feedback are most important for your students? 
Appendix G

Typo de Errores [Type of Errors] 
Tipo de errores

$$
\begin{aligned}
& \text { Adj }=\text { Adjetivo } \\
& \text { Art. = Artículo } \\
& \text { Cunjug = Conjugución del verbo } \\
& \text { Prep = Preposición }
\end{aligned}
$$

$\varnothing=$ Cambiar o Sacar Palabra

$$
\text { plur }=\text { plural }
$$

T Tiemp $=$ Tiempo del verbo / verb tense PunT = PunTuación

clar = claridad / ptase confusa.

Gend = Genero (masculino ófemenino)

Numb: Number (Singular ó plural)

Pron = Pronombre (subject pronoban, object, Possessive, $e+c$ !

$$
\text { vsa = vsage }
$$

$\omega_{0}=$ word order (Palabras inverti das)

Sub-verb = concordancien, sujeto-verb.

$L T / T L=$ Traducción Literal/-itera Translation

Spell = Spelling. 
Appendix $\mathbf{H}$

Guía para la Composición [Guide to the Composition] 
Guía para la composición:

SPAN İCOMPOSICIóN

CORRECCIóN:

ORT ORTOGRAFiA =Spelling Ej: $\stackrel{C \text { cuidad }}{\rightarrow} \underset{\mathrm{VOC}}{\rightarrow}$ ciudad

VOC VOCABULARIO Ej: Hay cuatro "shoping centers" $\rightarrow$ Centros comerciales

ORDER WORD ORDER ej.: "Vamos a un grande parque" ...a un parque grande.

EXPR EXPRESSION: use a structure studied in class.

Ej.: "En verano Morgantown esta caliente" $\rightarrow$ hace calor

Ej.: "Tengo gusto de ir a los bares" $\rightarrow$... me gusta ir a los bares. EXP

GRAM. GRAMáTICA GRAT

"Me gusta paseQ" GRAI $\longrightarrow$ Me gusta pasear

"Los árboles son muchos verdes" $\rightarrow$.. muy verdes

AGR. $\quad$ AGREEMENT $(=$ CONCORDANCIA $)$

“"Muchos personas de Cuba vive en Miami"-- -Muchas personas viven en Miami TGR. $\overline{A G R}$

VERB VERB + wrong verb used $\rightarrow$ "Son más de cuatro millones de personas en mi ciudad" S"Hay más de cuatro..." veRß

+Add a verb $\rightarrow$ "En inviemo nieva mucho y fmucho frio"... hace mucho frío (VERB:Couj)

VERB (conj.) "La gente jugar fütbol" $\longrightarrow$ "la gente juega futbol" $\operatorname{VERB}\left(A g r^{\circ}\right)$

VERB (agr.) "Las personas es muy sociables" $\rightarrow$ ‘Las personas son .."

? I don't understand what you mean

( ) Avoid this expression

PARA ESCRIBIR CON EL ALFABETO ESPAñOL:

\begin{tabular}{|c|c|c|c|}
\hline$A L T+164:$ & $\tilde{\mathbf{n}}$ & $\mathrm{ALT}+161: \mathbf{i}$ & $\begin{array}{l}\text { CONT. } \rightarrow \text { CONTENT } \\
\text { ORG. DRCANIZAATION }\end{array}$ \\
\hline ALT + $168:$ & i & $\operatorname{AlT}+162: \dot{\mathbf{o}}$ & Vor, $\rightarrow$ VOXABILARY \\
\hline ALT +160 & $\dot{\mathbf{a}}$ & ALT + 163:ú & LANG $\rightarrow$ LANGIAGE \\
\hline
\end{tabular}


Appendix I

Correction Chart 

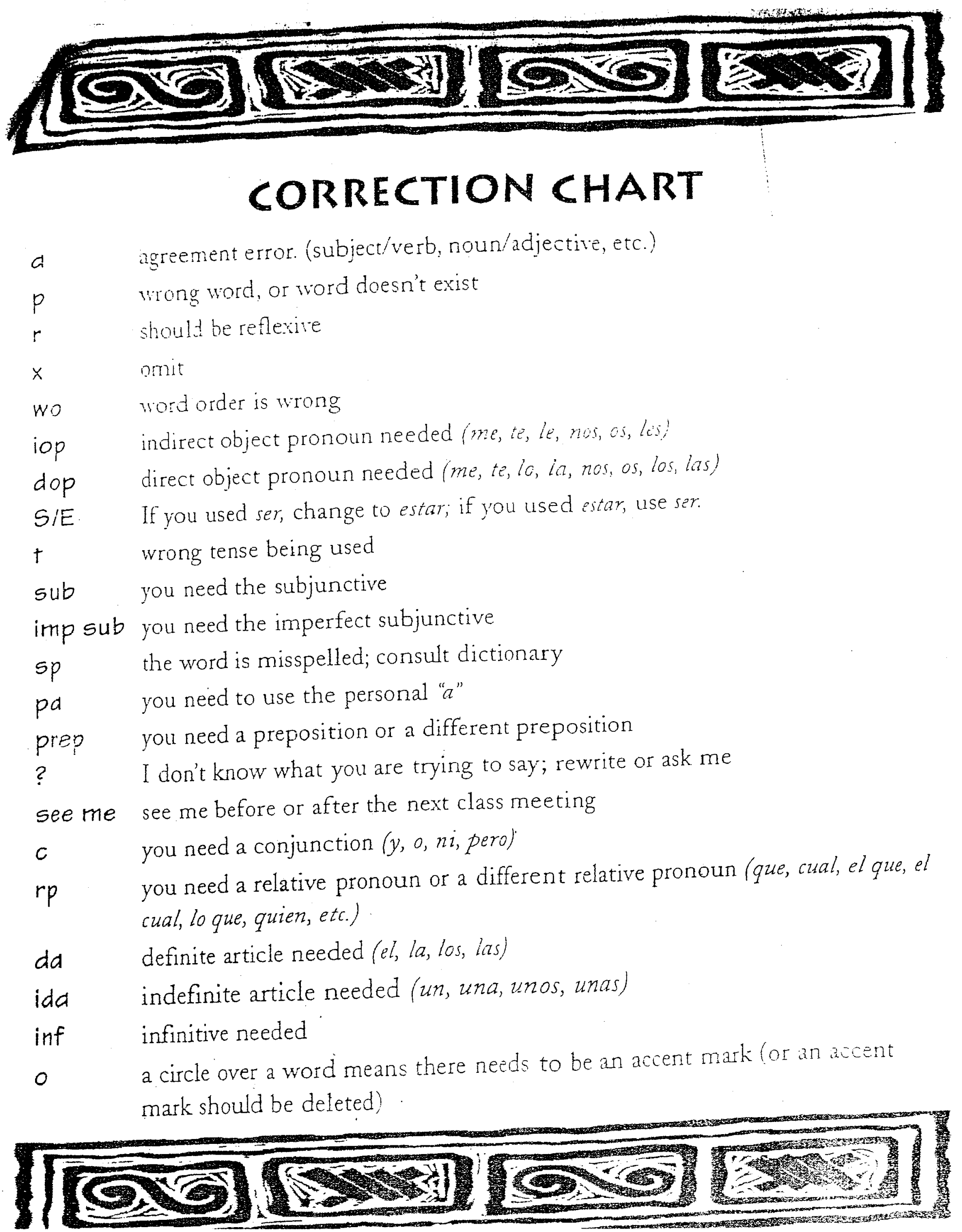
Appendix J

Course Objectives 


\section{Course Objectives \\ Spanish 101}

Course Objectives: Upon successful completion of this course, you should be able to:

1) SPEAK Spanish well enough to describe, narrate, and ask and answer questions in present time about everyday topics including greetings, addresses, introductions, information about classes daily routines/activities, describing oneself and one's interests, expressing likes and dislikes, and making plans.

2) COMPREHEND Spanish with sufficient ability to grasp the main idea and some supporting details in short conversations - both spontaneous and taped - that relate to daily life and represent authentic situations.

3) READ AND UNDERSTAND the main idea and some details of both edited and non-edited material, if highly contextualized.

4) WRITE sentences and paragraphs on familiar topics, complete forms and write notes, letters, and postcards that relate to personal interests and practical needs.

5) RECOGNIZE that basic cultural differences do exist and that learning a language enables a person to better understand and interact with the people who use the language natively.

\section{Course Objectives \\ Spanish 102}

Course Objectives: Upon successful completion of this course, you should be able to:

1) SPEAK Spanish well enough to describe, narrate, and ask and answer questions in present and past time about everyday topics including introductions, information about your family and places you have traveled to, describing one's interests, expressing likes and dislikes, talking about the weather and ordering meals.

2) COMPREHEND Spanish with sufficient ability to grasp the main idea and some supporting details in short conversations - both spontaneous and taped - that relate to daily life and represent authentic situations.

3) READ AND UNDERSTAND the main idea and some details of both edited and non-edited material, if highly contextualized.

4) WRITE sentences and paragraphs on familiar topics, complete forms and write notes, letters, and postcards that relate to personal interests and practical needs.

5) RECOGNIZE that basic cultural differences do exist and that learning a language enables a person to better understand and interact with the people who use the language natively. 
Appendix K

Compositions 


\section{Spanish 101}

Composición 1

Yukiko

\section{Mi ciudad, Regency}

Regency es una ciudad en el norte de Regency State en los Estados Unidos

habitanter año

Regency tiene una población de 81.0004 de 26.000 en el verano) en el dos mil.

Regency está cerca de Washington D.C. y Pittsburgh. También en Regency hay un aeropuerto y mi Universidad de Regency

La Universidad de Regency tiene muchas escuelas, pero los estudiantes pueden ir a ortas escuelas en el "PT" y el bus de RU. En 1 1 (s) Universidad de Regency hay muchas clases como el área de la ingeniería y la informática, de 0 ciencias y $10 \%$ artes,
derecho apee de la medicina, de teriodismo, de 105 attes, de agricultura, de la económiła y 1 empresariales y de la educación.

En la" RU " hay cuatro edificios importantes para la vida delestudiante. Son la

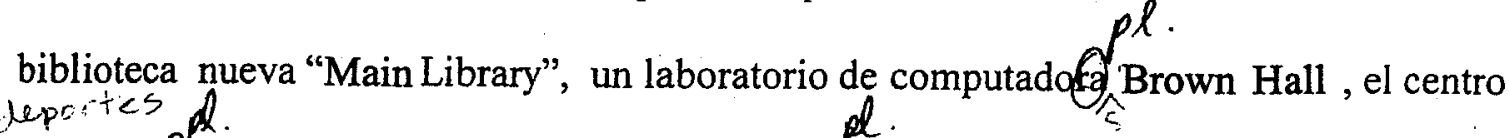
de deport." Sp Center" y un centro de estudiang." Lair Center". "Main Library" es

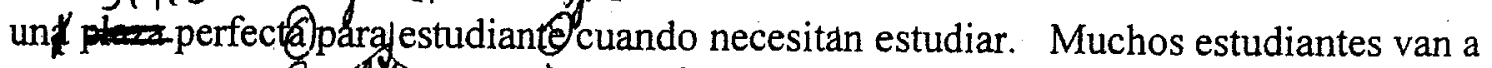
Brown Hall cuando escriban un ensayo académico o exploran en Internet. Muchas personas hacen ejercicio en "Sp Center" todo el tiempo. Todo 6 fin de semana hay $g$ soe actividades como" RU Fun Night" en el " Lair Center "para estudiantes. En el. Lair Center muchos van $\Theta$ cine, comen comida gratis y hacen actividades divertidas. spell. a bebictan Pero a veces los estudiantes pueden salir a bailar o pueden ir por o comida en Main Street . 
86

oragree

En(8) primavera en Regency hace buen tiempo. Muchos van a "Green Park "y or verb

pasean fun la montaña. En el verano, hace calor ythúmedo. Muchas personas van a wrong verts

"Blue Lake" o "Regen Park" y nadan. El otoño th Regency muy bien y ponita.

Disfrutan del color del otoño por todas partes de Regency. En el invierno van a

Central Hall en RU y les gustan sacar fotos de Central Hall con luces bonitas.

Mi ciudad es verdaderamente pequeña, segura y bonita. También la ciudad y la Spell.

Universidfte dan muchas oportunidades. Me gusta vivir en. Regency iVamos $a$ estudiar Wvivir en Regency ?

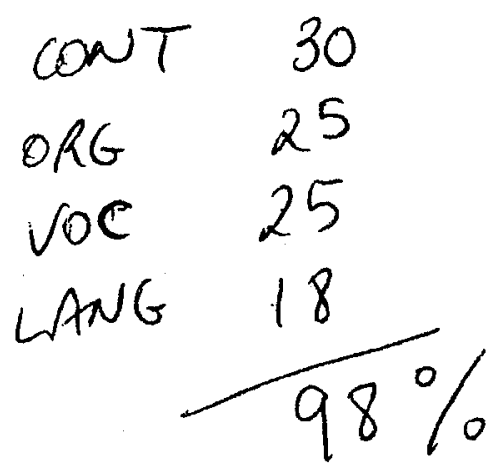

Mey bien

Yukiko 


\section{Spanish 101}

\section{Composición 1}

Yukiko

\section{Mi ciudad, Regency}

Regency es una ciudad en el norte deRegency State en los Estados Unidos.

Regency tiene una población de 81.000 habitantes (de 26.000 en el verano) en el año dos mil. Regency está cerca de Washington D.C. y Pittsburgh. También en Regency hay un aeropuerto y mi Universidad de Regency .

La Universidad de Regency tiene muchas escuelas. Pero los estudiantes pueden ir a otras escuelas en el “ PT” y el autobús de RU . En la Universidad de Regency hay muchas clases como el área de la ingeniería y la informática, de las ciencias y las artes, de la medicina, de derecho, de periodismo, de las artes, de atletismo, de la agricultura, de la economía y empresariales y de la educación.

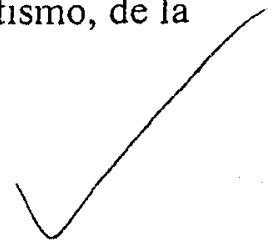

En la " RU " hay cuatro edificios importantes para la vida del estudiante. Son la biblioteca nueva"Main Library", un laboratorio de computadoras "Brown Hall", el centro de deportes " Sp Center" y un centro de estudiantes " Lair Center ". "Main Library" es un sitio perfecto para los estudiantes cuando necesitan estudiar. Muchos

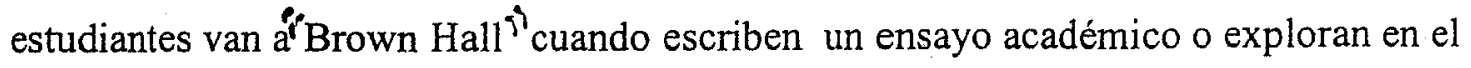
Internet. Muchas personas hacen ejercicio en "Sp Center" todo el tiempo. Todo el fin de semana hay actividades como " RU Fun Night" en el " Lair Center "para estudiantes. En el ${ }^{\prime}$ Lair Center ${ }^{\$}$ muchos van al cine, comen comida gratis y hacen actividades divertidas. Pero a veces los estudiantes pueden salir a bailar o pueden ir por una bebida o comida en 'Main Street" 
En la primavera en Regency hace buen tiempo. Muchos van a "Green Park "y pasean por la montaña. En el verano, hace calor y es húmedo. Muchas personas van a "Blue Lake" o "Regen Park" y nadan. El otoño Regency es muy bonita. La gente disfruta del color del otoño por todas partes de Regency. En el invierno van a Central Hall en RU y les gustan sacar fotos de Central Hall con luces bonitas.

Mi ciudad es verdaderamente pequeña, segura y bonita. También la ciudad y la Universidad dan muchas oportunidades. Me gusta vivir en Regency ¿Vamosa estudiar y a vivir en. Regency ?

$$
\text { Hey bien }
$$

Yukiko

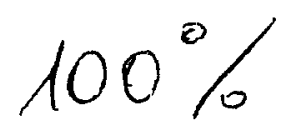



el rio Regency. Hay mucho tráfico. Hay muchas montañas. Regency estérca de Pennsylvania y Maryland.

Hay muchos ugares de interes. Hay "Blue Lake", "Rail Trail", " Green Park " y Dellen Center. A Muchos les gusta ir de compras en' Main Street ${ }^{3}$. Hay autobuses turístiogs. azlee. Hay muchas actividades sociales en Regency Fiestas en casas muy popu
muchos discotecas y bares. Muchas personas les gusta ver ufa peliculat cine. Hay muchas actividades sociales en Regency Fiestas en casas muy popu
muchos discotecas y bares. Muchas personas les gusta ver ufa peliculat cine.

En verano, hace mucho calor y humedad. Personas les gusta nadar en la piscine lagos "Red Fall" " "Blue Lake" son muy populare

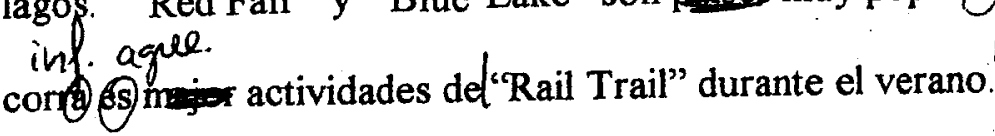

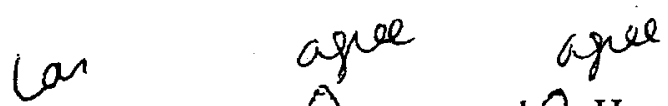
Fiestas en casas muy populat Hay

En otoño, hace buen tiempo. El fútbol americano es muy popular. Regency

es muy bonita en otoño.

En invierno, hace frío. Much les gusta esquiar nievej(en Sand y Harry Springs. powa

En primavera, hace buen tiempo. huchas les gusta camines eh el parque. La Universidad de Regency Tieve Regency. Esta universidad grande verb"

muchas estudiantes. muy bonitaedificios, por ejemplo, Central Hall,

"Lair Cente" "Sp Center" y 6 s burde deden

agree. 
90

Hays : para de Primaverg Durante éabado, "Fun Night.", Hácé depotalen "Sp Center"y He películas en el "Lair Center".

La universidad muchas cosas ofrece los estudiantes. $\left.{ }_{\sigma}^{\circ} \mathrm{H}\right)$ " $\mathrm{Sp}$ word onder Center", bibliotecas, "P T ", "Lair Center ", etc.

La universidad ofrece muchas clases ${ }_{0}^{o} \mathrm{H}$ je económicas, matematicas, cofmmunicación, historia, ciencias politicas, etc. speto.

Regency y la universidad es muy bien paises. no entiando!

Wak in the pood pow thimgs and you'll
CONT. 27

ORG. 23

VOC. 24

LANG. 16 be fine.

$90 \%$

2

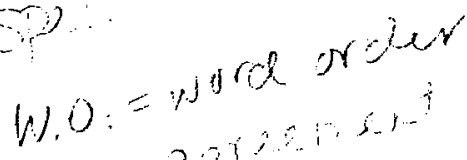

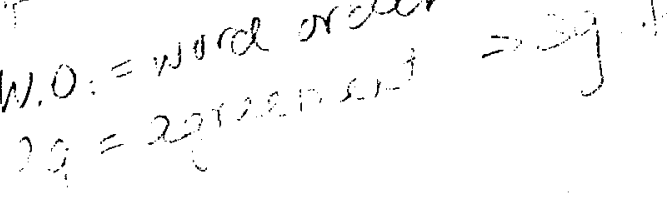


Julie

Spanish 101 Composition

7-22-02

\section{La Vida en. Regency}

"Paradise" por muchos visitantes. Regency es una ciudad pequeña en las

Regency es un gran lugar con mucho continuar y sido refered como a montañas de Regency y está situado en el río \$a Regency Nuncahay agpex.
montañas de in momento aburrido. ; La escena social es salvaje! El) fintes de semana, la gente va(n) a bailar los clubs, ags barriss o los partidos then "Blue Lake ", el "Sellen Center", hl Green Park ", y el (rastro del carril para montar en bicicleta. Regency también tiene und (tameda) de compras y algunos para wong wid toton

teatros detu película. Las actividades de la gente dependen de cuál es el tiempo.

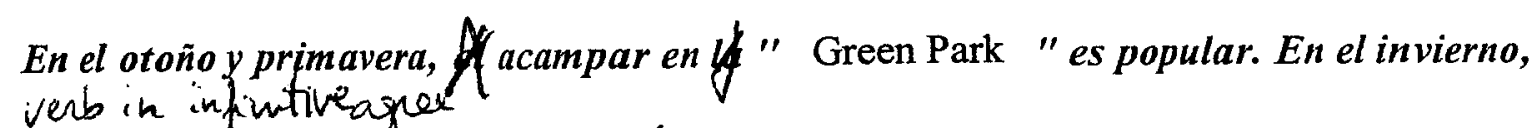
Iteses los deportes en el nuevo" Sports Center "es popular. El verano es la estación más reservada de Regency porque van la mayoría de los estudiantes de RU a casa.

Regency es el hogar de la universidad de Regency State "La mascota para

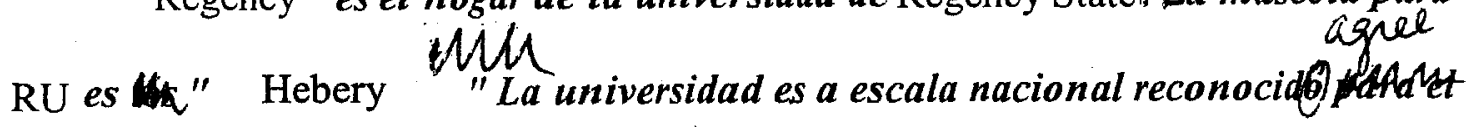

SU a excelencia académica y programa grande de deportes. iEl campus de RU es hermoso! Localizado en el corazón de Regency Tlosedificios son magnificos.

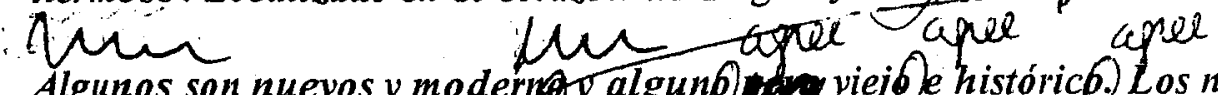
Algunos son nuevos y moderyoy algun6) viejêle históric 6 . Los nombres de hur cipee alguinos de los son: Diamon , Willow, Brown y Central Hall.

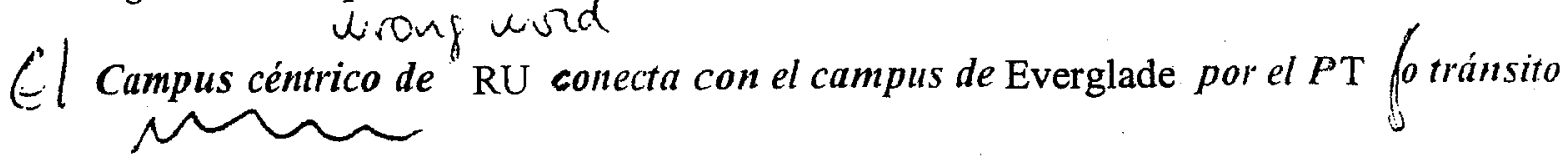


rápido persona El PRT fue votado uno los mejores "motores de gente" de los E.E.U.U..

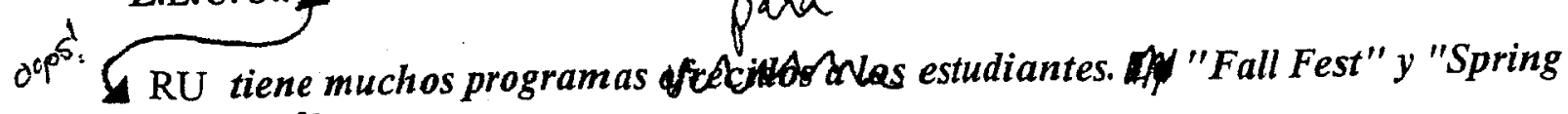
aglel

Fest" es conciertos anuales llevados en el " Lair Center " (unión del estudiante).

"RU Fun Night"las tardes de jueves,

atis y hospitalidad. El nuevo" Sports Center "tiene todo pesos a pared que sube de la roca muy grande. Todos los acontecimientos de los deportes de RU apree

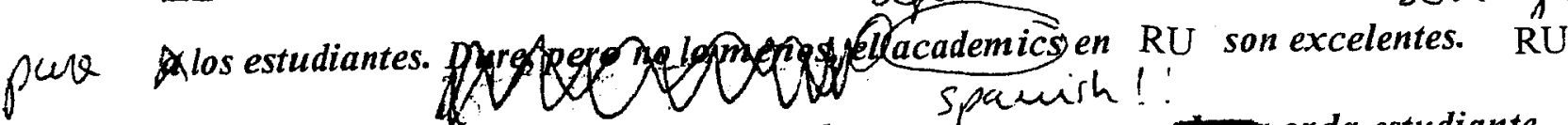
ofrece una amplia gama corash spamas para

\section{de ple}

Porque RU es una universidad muy grande, las clasen también

grandes. Pero las clases especializadas se convierten, más pequeñas consiguen. Los

profesores tienen horas de oficina y contestarán siempre a pregun@.

$$
\text { no eu tiendo! }
$$
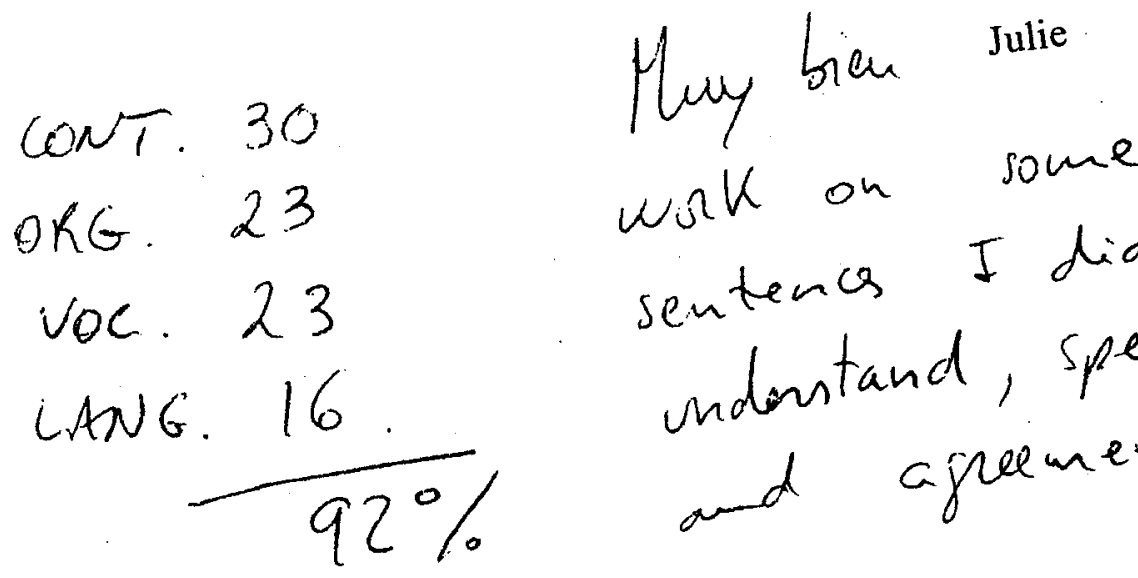

work on some sentence I didin undontand, spelliry 
Anna

Spanish 101

Composition Draft

La vida en Regency es una divertida experiencia. Estâ muchos lugares de interés y hay muchas cosashacer. Regency está en Regency State Yo vivo en Regency . por tres años. La ciudad es muy bonita, especialmente en la primiera. Es pequêfa cuando los estudiantes hy notaquí. Hay muchas montañas. Mo hay parking y mucho tráfico.

En. Regency bay muchos lugares de interés. Tu(tatair a " Red Fall " o " Green

Park" Me gusta ir d. Regency Mall", ir de compras o pasear en barca en "Blue Lake ." El centro de Regency es Regency Injiversidad. Hay muchas actividades sociales. Ini

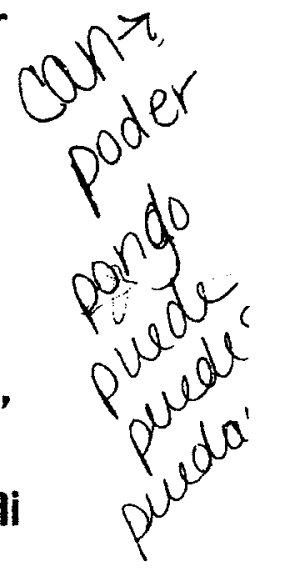
fauorita cosa es jilgar al boliche. Parafin de semana hay muchas discotecas y bares. word onder muy barato ef Juevestpor chicas en Gudiscotecas porque es "Señoritas noche." me spell. encanta salir a bailar. Ille gusta ir at cime'y jugar filtar.

En . Regency en elfuerano hace mucho calor y mucha humedad. Es aburrido porque los estudiantes hay nolaquí, pero hay pequefíctósas a tree

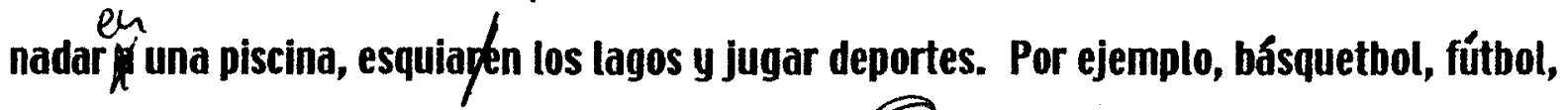
tenis, y béisbol. En el otoîo hace buen tiempo. Iflatgasear en el parque o ir a los fútbol partidos. Hay fiestase Dia de las Brujas. Es muy divertido. En el invierno hace mucho frío W. 0.0 ague y nieue. Unas actividades son ir a esquiar a "Sandy' ir al cine, y comer fuera. Hay muchas

fiestas en casas. En la primavera hace buen tiempo. Th lata mirar las flores o ir de compras pula popr nueva ropa. $?$

La Universidad es el centro de la ciudad. Hay muchos bonitos edificios.Central Halles

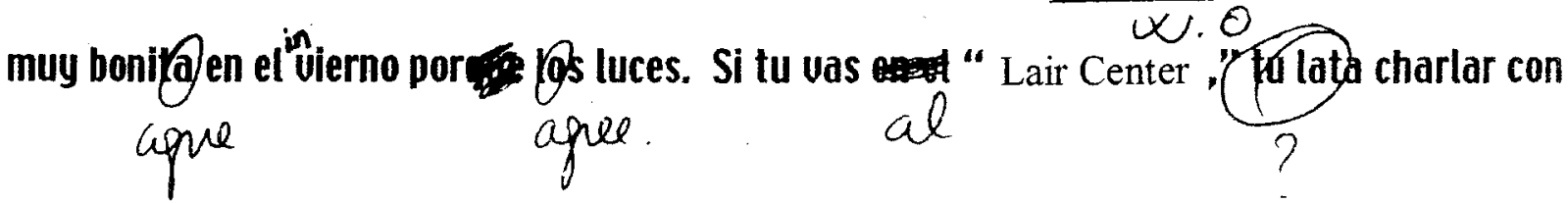


94

infin.

trabajo

tus amigos o estudiar. me gusta ejercicio thel " sports Center " o escribir el ou (Nomputadora laboratorio. Hay muchos libros $K$ las biblotecas y muchos dormitorios en $e l$ Worl scter campus. La Universidad constrya nuev6 "Sciences Building " Hay muchas divertidas actiuldades. Por ejemplo, ¿

el " Sports Center ." agree.

Unfof cosas que ofrece son "P T, " películas en el " Lair Center ," partidos, y apree descuentos en el campus. Hay dos campuses, "Everglade" y "Downtown." Unigs clases que se ague ofree en el "Everglade" son arquitectura, educación, ingeniería, y facultad de bellas

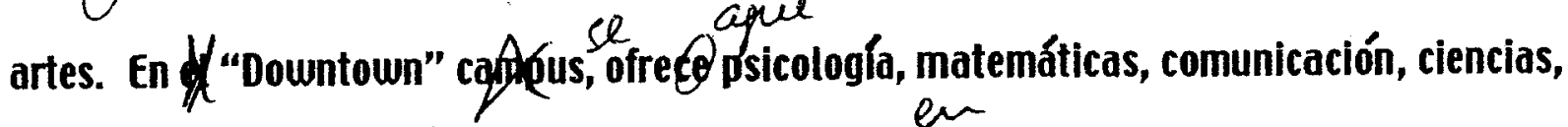
sociología, y muchas más. Yo aprendo muchas cosas ${ }^{\prime}$ la Universidad. Primero, es necesario asistir tof clases. Segundo, es muy importante tomar apuntes. Por último, no beber mucha apee cerleza en noches de escuela.

spell.

Mury bian

CONT. 30

Anna

ORG. 24

Uac. 23

LANG 17

$94 \%$ 
La vida en Regency es una experiencia divertida. shy muchos lugares de interés y hay muchas cosas para hacer. Regency está en Regency State. Yo vivo en Regency por tres años. La ciudad es muy bonita, especialmente en la primavera. Es pequeña cuando los estudiantes no hy

En Regency hay muchos lugares de interés. Tu puedes ir a "Red Fall " 0 “Green Park " Me gusta ir a " Regency 'Mall," ir de compras o pasear en barca en “Blue Lake." El centro de Regency es La Universidad de Regency : Hay muchas actividades sociales. mi cosa favorita es jugar al boliche. Para el fin de semana hay muchas "La noche de les Señoritan"

discotecas y bares. "Sefín es muy barato el Jueves para chicas en las discotecas. Me encanta salir a bailar. Me gusta ir al cine y jugar al billar.

En Regency en el verano hace mucho calor $y$ mucha humedad. Es aburrido están.

porque los estudiantes no the aquí, pero hay pequeñas cosas: nadar en una piscina, esquiar en los lagos y jugar deportes. Por ejemplo, básquetbol, fútbol, tenis, y béisbol. En el otoño hace buen tiempo. Tu puedes pasear en el parque o ir a los partidos de fútbol. Hay fiestas el Día de

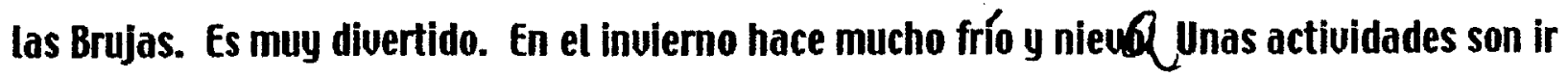
a esquiar a 'Sandy, ir al cine, y comer fuera. Hay muchas fiestas en casas. En la primavera hace buen tiempo. Tu puedes mirar las flores o ir de compras para ropa nueva.

La Universidad es el centro de la ciudad. Hay muchos edificios bonitos.Central Halles muy bonito en el inuierno por las luces. Si tu vas al "Lair Center " tu puedes charlar con tus amigos o estudiar. Me gusta(Mer)ejercicio en el “ Sports Center ” o escribir el trabajo $\operatorname{lna} 0 \Omega$ 
96

enlaboratorio tomputadordy Hay muchos libros en las biblotecas y muchos dormitorios en el campus. La Universidad construy s nuevol " Sciences Building :" Hay muchas actividades dluertidas. Por ejemplo, El festival de Otoño y Primavera, "RU Fun Might", y deportes en el “ Sp Center .”

Unas cosas que ofrece son el "PT ," películas en el " Lair Center ," partidos, y descuentos en el campus. Hay dos campuses, "Everglade "y "Downtown." Unas clases que Nof ofrec $f^{\mu /}$ en el "Everglade" son arquitectura, educación, ingeniería, y facultad de bellas artes. En "Downtown," se ofrecPosicología, matemáticas, comunicación, ciencias, sociología, y muchas más. Yo aprendo muchas cosas en la Universidad. Primero, es necesario asistir a las clases. Segundo, es muy importante tomar apuntes. Por último, no beber mucha cerveza en noches de escuela.

Mey bien Anna 
Josh

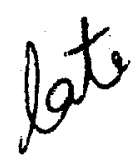

\section{Composicion}

$7 / 22 / 02$

La universidad de Regency

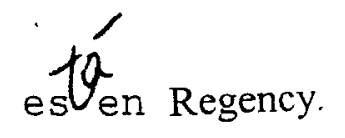

Regency tiene muchas cosasphacer. En la ciudad de Regency hay muchos bares and discotecas. Me gusta bailar y beber muchas cervasps. Regency es pequeriog ag. bailar yelling pero muy bonita y montañosa. Tu puedes ir de compras en Main calle, jugaralolf, y hacer ejercicio en el centro de recreo.
En verano $\stackrel{\mu}{R e g e n c y}$
hace calor y/muy humido, pero en

los edificios hace buen tiempo. En la primavera y otoño hace buen tiempo, también. (Nace frío y nieva en inviernos de Regency. spell?

La universidad tiene muchos aglases. En Everglade

la gente toma k clases de biología, ingeniería y geología. En
el main cempus gente dour clases de economía, química, Tu puedes el PT a clase. La universidad tiene muchos deportes. Me gusta ver fútbol americands en $^{\text {el }}$ ustiod 20 stadium, pero hay otra deprtes nos juegan. Hay beisbol, Spayth futbol, y baloncesto. Thudo lagestudientes. En $\frac{\text { los }}{5 q}$ tiempo libre, las estudientep spell.
pueden ver gente tocar la guitaray cantar, en fel festivai
fow. 
98

de otoño o primavera. Hay también, RU todos noche. Aquŕ 10s estudientes comef, bebel cervasas, charly con amigos,

agee jogr billar o boliche. ague spell. agee. apree.

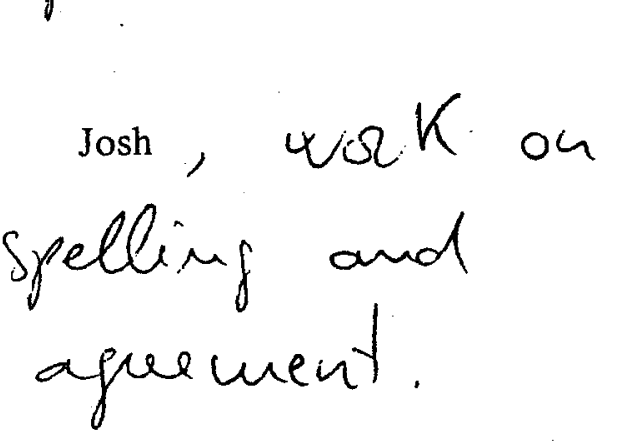

$$
\begin{aligned}
& \text { CONT. } 28 \% \\
& \text { ORG. } 23 \\
& \text { VOC. } 23 \\
& \text { LANG } \frac{16}{90 \%}
\end{aligned}
$$


Josh

Composicion

$7 / 31 / 02$

La universidad de Regency está en Regency.

Regency tiene muchas cosas para hacer. En la

ciudad de Regency hay muchos bares y discotecas. Me

gusta bailar y beber muchas cervezas. Regency es

pequêra, pero muy bonita y montar̂osa. Tu puedes ir de

compras en Main calle, jugar al golf, y hacer ejercicio en

el centro de recreo.

En verano en Regency hace calor y es muy húmido, pero en los edificios hace buen tiempo. En la primavera y otóno hace buen tiempo, también. Hace frío y nieva en los inviernos de Regency.

La universidad tiene muchas clases. En Everglade la gente toma clases de biología, ingeniería y geología. En el Main campus la gente toma clases de económicaf químíca, histor $d_{a}$ informátíca y psicología. Los clases aquí son

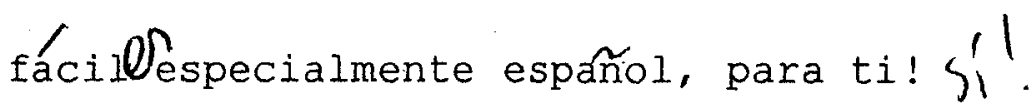

Tu puedes tomafel PT a clase. La universidad tiene muchos deportes. Me gusta ver fútbol americano en el estadio. Hay béísbol, fútbol y baloncesto, también. Ia universidad tiene muchas cosas para los estudiantes. En $\rightarrow \int_{t}$ L tiempo libre, los estudiantes pueden ver gente tocar la guitarra y cantar, en los festivales de otoro y primavera. 
100

Hay también, RU tiene a la noche durante la fin de semana comida y los refrescos para los estudiantes. AquÍ, ios no emtiendo estudiantes charlan con amigos y juegan billar o boliche.

$$
\text { Hey bien }
$$

$$
98 \%
$$


Mike

\section{Mi compañero en la clase de español}

En la clase de español, me siento en la silla al lado de Rick Moore . Tiene ojos azules, el pelo marron y cortos, y lleva lentes. El siempre es lleviendo ropas muy bien, generalmente una

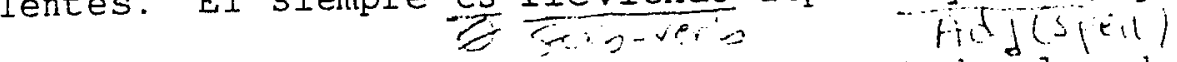
camisa, pantalones, corbata y zapatos, todos $\frac{10 s}{\frac{10}{3}}$ de lujo.

Rick trabaja en Moab como un interno. El es un técnico de la computadora. El dice que él trabaja con la cabeza y los manos. Sus habilidades están en el hardware de la computadora, el software de la computadora y escritura técnica.

Su rutina diaria comienza con el empleo a las siete en la mañana hasta las ocho y media. Entonces él va a la clase de español a las nueve hora hasta las diez y cuarto. A las diez y media él asiste la clase de la historia. Entonces a las doce menos cuarto sale la universidad y va a trabajar en Moab. Sale el trabajo a las siete, hora por la noche ver a la casa. A veces va al bar por bebiendo y bailando.

Rick dice que él no tiene mucha vez para otra cosas. El haces mucho trabajo y escuela y estudiando. Pero tiene otros

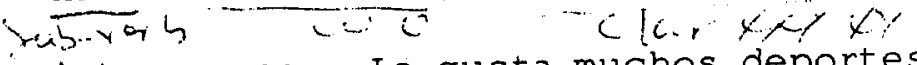

interesarse. Le gusta muchos deportes, pero su favorito es el hockey. Su equipo favorito es las Alas Rojas de Detroit, Michigan. Juega la guitarra, lea los libros, escucha música, y viaja en su tiempo libre.

El dice no tener futuro inmediato planeas. Le glista su vida mucho.

$$
\text { buen Contenido y organizacion! }
$$




\section{Grading Criteria for Compositions}

Content (Information Conveyed)

- minimal information; information lacks substance (superficial); inappropriale or irrelevant information; or not enough information to evaluate.

Points

$15-18$

$19-22$

- limiled infomation; ideas present but not developed; lack of supporting detail or evidence.

$23-26$

- adequate information; some development of ideas; some ideas lack supporting detail or evidence.

$27 \widehat{30}$

- very complete information; no more can be said; thorough, relevant, on target.

Organization

- series of separate sentences with no transitions; disconnected ideas; no apparent order to the content; or not enough to evaluate.

$12-15$

- limited order to the content; lacks logical sequencing of ideas; ineffective ordering;

very choppy, disjointed.

$16-19$

- an apparent order to the content is intended; somewhat choppy, loosely organized but main points do stand out although sequencing of ideas is not complete.

$20-22$

- logically and effectively ordered from introduction to conclusion; main points and details are connecied; fluent.

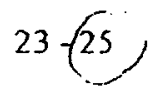

Vocabulary

- isadequate, repetilive, incorrect use or non use of words studied; literal translations; abundance of invented words or words in English; or not enough to evaluate.

$12-15$

- erroneous word use or choice leads to confused or obscured meaning; some literal translations and invented words; limited use of words studied.

$16-19$

adequale but not impressive; some erroneous word usage or choice, but meaning is not confused or obscured; some use or words studied.

- broad; impressive, precise and effective word use/choice; extensive use or words sndied.

\section{Language}

- abundance of errors in use and form of the grammar presented in lesson; frequent errors in subjectverb agreement; non-Spanish sentence structure; entoneous use of language makes the work mostly incomprehensible; no evidence of having edited the work for language; or not enough to evaluate.

- frequent errors in use and form of the grammar presented in lesson; some errors in subjectverb agreement; some errors in noun/adjective agrcement; erroneous use of language often impedes comprehensibility, work was poorly edited for language.

- occasional errors in use and fonn of the grammar presented in lesson; occasional errors in subject/verb or noun/adjective agreement; erroneous use of language does not inpede comprebensibility, some editing for language evident but not complete.

no errors in the grammar presented in lesson; very few etrors in subject/verb or noun/adjective agreement; work was well edited for language. 
Mike

Composición 1 Final Draft

Mi compañero en la clase de español

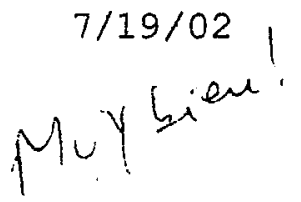

En la clase de español, me siento en la silla al lado de Rick Moore . Tiene ojos azules, pelo marron y cortos, y lleva lentes. El siempre tiene ropas buena; generalmente una camisa, pantalones, corbata y zapatos, todos de lujo.

Rick trabaja en Moab. como un interno. El es un técnico de la computadora. El dice que él trabaja con la cabeza y las manos. Tiene lás habilidades en el hardware de la computadora, el software de la computadora y escritura técnica.

Su rutina diaria comienza a témor a las siete de la mañana hasta las ocho y media. Rick va a la clase de español dujde las nueve róa hasta las diez y cuarto. A las diez y media él asiste la clase de la historia. Luego, a las doce menos cuarto de sale ila universidad y va a trabajar en Moab. Sale del trabajo a J las siete $\underset{x}{ }$ la noche vela la casa. A veces va al bar a beber y bailar.

Rick dice que él no tiene muche tiempo para otrás cosas. El usa casi todo su tiempo Ge trabajar, ir a escuela, y estudiar. Pero tiene otros intereses. Le gusta muchos deportes, pero su favorito es el hockey. Su equipo favorito es las Alas Rojas de Detroit, Michigan. Toca la guitarra, lee los libros, escucha música, y viaja en su tiempo libre.

El dice no tener planeps futurd inmediato: Le gusta su vida mucho. 


\section{Angela}

Espanol 102

Composition \#1

Diane es mi companera en mi clase de español. Ella tiene viente años. Diane es muy simpática y extrovertida. Ella vive en Regency con tres amigas. $\frac{\text { Sula familia es }}{\text { Pron }}$ muy grande. Diane tiene dos hermanas y tres hermanos.

Su

Ella familia viven en Nueva Jersey. Diane estudia Pron $\circlearrowright$ psicología y español en la universidad. $\frac{\text { Ella clase }}{\text { Toun }}$ favorita es español porque el profesor es muy interesante y muy divertido. Le gusta jugar el fútbol por la

universidad. Ella es muy buena deportista. Diane es azules bonita. Su pelo es rubio y lacio. Sus ojos son azuli sus dientes grandes y sonrisa es muy atractiva. Ella es alta y delgada. Las piernades muy fuertes porque jugar el fútbol. Sus actividades incluir jugar el futbol, bailar en la discoteca, beber y comer, y dormir. Diane le gusta comer Su

pollo y pasta. $\frac{E I}{\text { Pron }}$ resturante favorita es Today's . Le gusta $\frac{\text { van al al resturante con sus amigas. Sul discoteca }}{\text { Lubrerh }}$

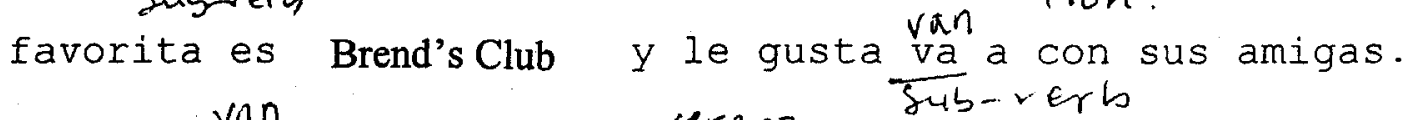
Le gusta va a la playa en verno con sus amigas. Diane le

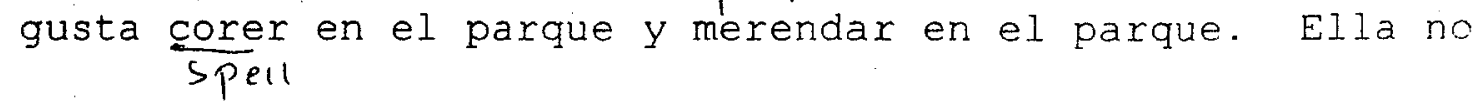
le gusta estudiar en la biblioteca porque es muy silencio y muy aburrida.

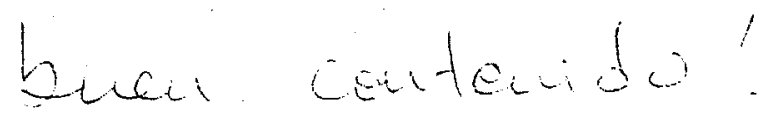


Ella quisiera entrar al trabajo despues $\underset{n}{\mathrm{j} g} \mathrm{~g}$ a viajar con sus amigas en el verno. Van a Caribbean hace spell spel. porque es mucho calor. Le gustaria seguir una carrera en sub verb psicología y quisiera ganr mucho dinero. Diane quisiera jugar el fútbol y trabajar en el futuro. Eventualiadal Ella quisiera empezar una familia. Ella prefiere esperar para empezar una familia y quisiera trabajar primero. 


\section{Grading Criteria for Compositions}

Content (Information Conveyed)

Points

minimal information; information lacks substance (superficial); inappropriale or ire elevant information; or not enough information to evaluate.

$15-18$

$19-22$

limited information; ideas present but not developed; lack of supporting detail or evidence.

$23-26$

adequate information; some development of ideas; some ideas lack supporting detail or evidence.

Organization

very complete information; no more can be said; thorough, relevant, on target.

$12-15$

content; or not enough to evaluate.

$16-19$

very choppy, disjointed.

- an apparent order to the content is intended; somewhat choppy, loosely organized but main points do stand out although sequencing of ideas is not complete.

$20-22$

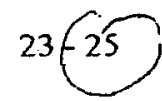
connected; fluent.

Vocabulary

- inadequale, repetitive, incorrect use or non use of words studied; literal translations;

abundance of invented words or words in English; or not enough to evaluate.

$12-15$

erroneous word use or choice leads to confused or obscured meaning; some literal translations and invenied words; limited use of words studied.

$16-19$

adequate but not impressive; some erroneous word usage or choice, but meaning is not confused or obscured; some use or words studied.

2022

$23-25$

\section{Language}

broad; impressive, precise and effective word use/choice; extensive use or words studied. enough to evaluate.

abundance of errors in use and form of the grammar presented in lesson; frequent errors in subject/verb agreement; non-Spanish sentence structure; erroneous use of language makes the work mostly incomprehensible; no evidence of having edited the work for language; or not agreement; some errors in noun/adjective agrcement; erroneous use of language often impedes comprehensibility, work was poorly edited for language.

- occasional errors in use and form of the grammar presented in lesson; occasional errors in subject/verb or noun/adjective agreement; erroneous use of language does not impede comprehensibility, some editing for language evident but not complete.

no errors in the grammar presented in lesson; very few entors in subjeclverb or noun/adjective agreement; work was well edited for language. 
Angela

Espanol 102

Composition \#1

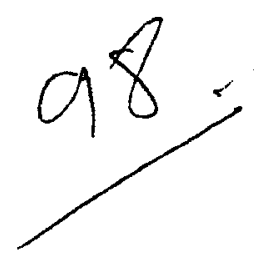

Diane es mi companera en mi clase de espanōl. Ella tiene viente años. Diane es muy simpática y extrovertida. Ella vive en Regency con tres amigas. Su familia es muy grande. Diane tiene dos hermanas y tres hermanos. Su familia viven en Nueva Jersey. Diane estudia psicología y español en la universidad. Su clase favorita es español porque el profesor es muy interesante y muy divertido. Le gusta jugar el fútbol porala universidad. Ella es muy buena deportista. Diane es bonita. Su pelo es rubio y lacio. Sus ojos son azules. Sus dientes grandes y sonrisa es muy atractiva. Ella es alta y delgada. $v$ Las piernas son

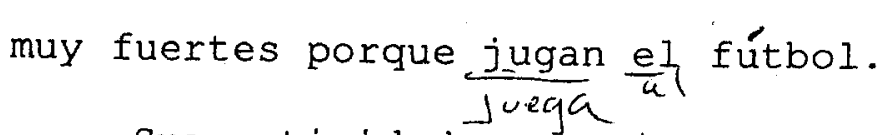
Sus actividades son jugar el fútbol, bailar en la discoteca, beber y comer, y dormir. Diane le gusta comer pollo y pasta. Su resturante favorita es Today's . Le gusta $\frac{\text { van }}{i r}$ al resturante con sus amigas. Su discoteca favorita es. Brend's Club y le gusta $\underset{i r}{\text { van }}$ con sus amigas.

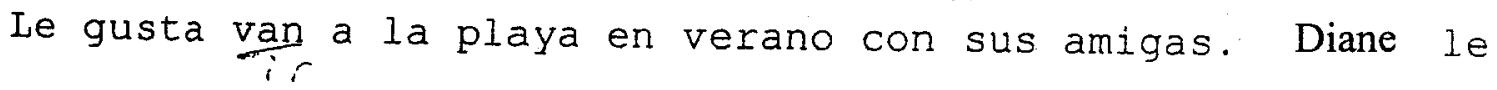
gusta correr en el parque $y$ merendar en el parque. Ella no le gusta estudiar en la biblioteca porque es muy aburrida. 
Ella quisiera entrar al trabajo después de graduarse. va a viajar con sus amigas en el verano. van alcaribłe porque hace mucho calor. Le gustaría seguir una carrera en psicología y quisiera ganar mucho dinero. Diane quisiera jugar el fútbol y trabajar en el futuro. Ella quisiera empezar una familia. Ella prefiere esperar para empezar una familia y quisiera trabajar primero.

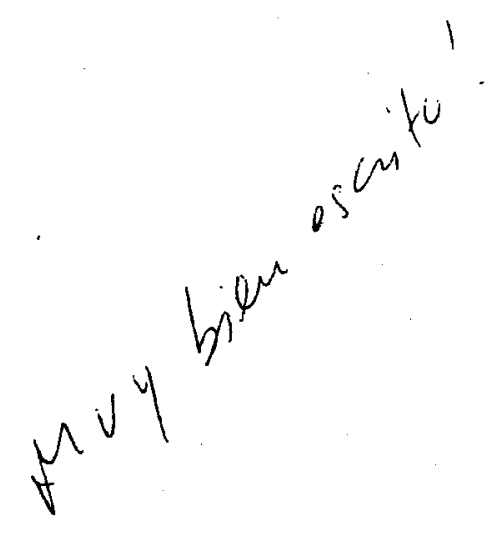


Henry

Espanol 102

$7-12-02$

$1^{\text {st }}$ Draft

Mi compañero nombre es John Martin. John es aproximadamente 35 años y

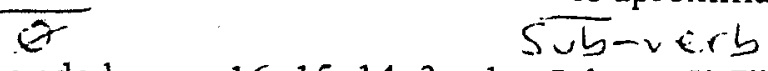

él tiene cinco hijos. Ellos edades son $16,15,14,3$ y 1 . John es 5 , 7" alto y pesar 185

$$
\text { Tron sub-verb jub-veab }
$$

libras. Su apriencia fisica consiste de ojos castano claro, pelo castaño corto y una barba.

Clar.

Mi amigo tiene un tatuaje en su brazo derecha. El tatuaje dice "Jane."

$$
\text { cend }
$$

John tiene más personalidades. Él es simpático, reservado, y de calcular. En la

escuela John es muy nervioso y tímido, pero cuando es en publica él es despacioso.

John no tiene algun preocupacíones.

$$
\text { sub-verb clar }
$$

John $v$ gusta hacer mucho actividades. Él gusta perros, gatos, pájaros, todos deportes, ver a los cines y viajar a otras ciudads. Cuando él viaja el ir a la playa o parques Elir. Spell. Sub-ver'b.

de nacionales. En el parque va a caminar y acampar con sus familia John mucho gusta numb ư.

ir al aire libre. La historia es su clase favorito en la universidad. Especialmente.historia Genut. iret $\frac{\text { ese es por aqui guerras. Él prefiere trabajar solo. Él gusta a barbacoa en la casa y comer }}{\text { Clar. }}$ en los restaurantes. John tiene dos aversiónes con escuela. Hay tomar los examenes y trabajar en grupos John no hace fumar o beber cervezas, tambien.

$$
\text { O sub-verh. }
$$

Su especialidad en Universidad de Regency es ciencias politico. John graduarse en dos años. Luego él voy a escuela ley.

$$
\text { oendinumb }
$$


Henry

Español 102

7-12-02

Final Draft

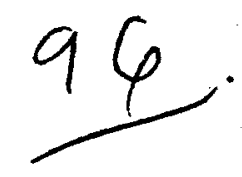

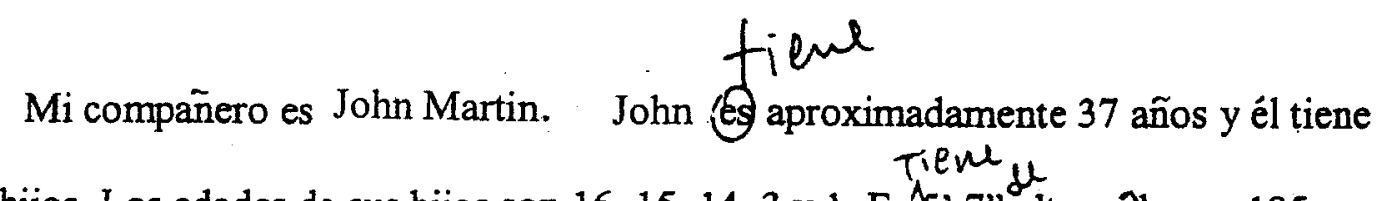
cinco hijos. Los edades de sus hijos son 16, 15, 14, 3 y 1 . Es' ${ }^{\prime}$ ' 7" alto y pesa 185

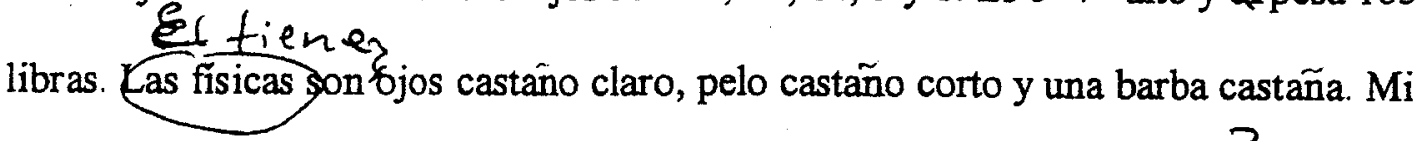
amigo tiene un tatuaje en su brazo derecho. El tatuaje dice "Jane" El servio en castrense de Estados Unidos.

John tiene muchas personalidades. Él es simpatico, reservado, inteligente, trabajador y práctico. En la escuela él es muy nervioso y tímido, pero cuando él es es en pública él es muy activo. John no tiene âgung preocupacíones. No es perezoso, aburrido y tacaño tambier.

$\operatorname{Los}$
John le gusta hacer muchas actividades. Le gustá perros, gatos, pajaros, todos deportes y viajar a otras ciudades. Él fue al cine con su esposa la semana pasada. Cuando él viaja él fue a la playa o parques dé nacionales. En el parque va a caminar y acampar con su familia. John le gustaijal aire libre. La historia es su clase favorita en la universidad. Especialmente la historia acerca de la Segunda Guerra Mundial. Él prefiere trabajar solo. Le gusta a barbacoa en la casa y comer en los restaurantes. No le gusta tomar los examenes y trabajar en grupos. John no fuma o bebe cervezas, tanatien. Su especialidad en Universidad de Regency es ciencias politicas. John Il gradua en dos anos. Luego fá a escuela leyes

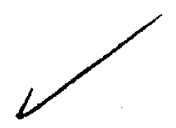

$$
\text { nuedeo nejo'. }
$$


Henry

Español 102

$1^{\text {st }}$ Draft

Claudia Reyes fue asesinato en 14 de marzo. Ese fue un Lunes. Ella acostado en missing $45 / \varepsilon$

piso cerca de la puerta. El correo fue en piso. La puerta fue abrir. Senora Reyes moriö a<smiles>c1ccc(C2CC2)cc1</smiles>

las tres hora. Hay tres posibles sospechosos para el asesinato: el cartero, su marido y la $x$

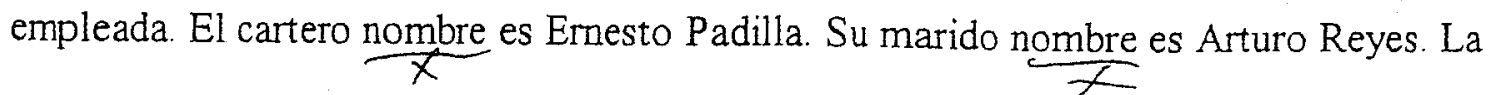
empleada nombre es Dulce Ramos.

$\bar{x}$.

Arturo Reyes testificó primero. El dijo:

(2) El cartero fue enamorado de mi esposa. Pero Claudia no le gusta Emesto. $5 / \varepsilon$

Claudia dijo "me gusta mi marido y no tu. "Ernesto fue muy enojado. El-mató con arma-eerca de puerta. Luego dejo la casa.

$$
\text { mastinde } \mathrm{STE}
$$

\section{Ernesto Padilla testificó segúnda. El dijo:}

(4) En 14 de marzo yo fui en mi casa. Yo fuimuy enfermo en lunes. Fui en mi cama todo el día. Mi espose dió me medicina. Ella tomo mi tempertura a las tres. (5) $\begin{gathered}\bar{\sigma} \\ \text { Yo tuvo no razon morir Claudia. }\end{gathered}$

\section{Dulce Ramos testificó tercero. Ella dijo:}

6) Ko ví Arturo morir su esposa. El mató con arma Claudia. Fui en la puerta de la sala. Arturo fue muy enojado con Claudia. Ella durme con su doctor muchos veces. $\overline{s / \varepsilon}$

(j) El jurado dijo "Nosotros encuentramos Senor Reyes CULPADO de asesinato." El jurado creio la declaracion de la empleada. Luego Arturo puse de pie y dijo "Ella merecio sp

morir. Ella durme con su doctor diez veces por la semana pasada. El juez sentencio Senor Reyes a vida en prision.

$$
\frac{\text { por la semana pasada. El juez sentencio Senor }}{x}
$$




\section{Grading Criteria for Compositions}

Content (Information Conveyed)

- minimal information; information lacks substance (superficial); inappropriate or irrelevant information; or nol enough information to evaluate.

Points

$15-18$

- limiled information; ideas present but not developed; lack of supporting detail or evidence.

$19-22$

- adequate information; some development of ideas; some ideas lack supporting detail or evidence.

$23-26$

- very complete information; no more can be said; thorough, relevant, on target.

\section{Organization}

- Series of separate sentences with no transitions; disconnected ideas; no apparent order to the content; or not enough to evaluate.

- limited order to the content; lacks logical sequencing of ideas; ineffective ordering; very choppy, disjointed.

- an apparent order to the content is intended; somewhat choppy, loosely organized but main points do stand out although sequencing of ideas is not complete.

- logically and effectively ordered from introduction to conclusion; main points and details are connected; fluent.

Vocabulary

- inadequate, repetitive, incorrect use or non use of words studied; literal translations; abundance of invented words or words in English; or not enough to evaluate.

- erroneous word use or choice leads to confused or obscured meaning; some literal translations and invented words; limited use of words srudied.

- adequate but not impressive; some enroneous word usage or choice, but meaning is not confused or obscured; some use or words studied.

$20-22-2$

$23-25$

broad; impressive, precise and effective word use/choice; extensive use or words studied.

\section{Language}

- abundance of errors in use and form of the grammar presented in lesson; frequent errors in subject/verb agreement; non-Spanish sentence strucrure; erroneous use of language makes the work mostly incomprehensible; no evidence of having edited the work for language; or not enough to evaluate.

- frequent errors in use and form of the grammar presented in lesson; some errors in subjecvverb agrecment; some errors in noun/adjective agreement; erroneous use of language often impedes comprehensibility, work was poorly edited for language.

occasional ertors in use and form of the grammar presented in lesson: occasional errors in subject/verb or nour/adjective agreement; ertoneous use of language does not impede comprehensibility, some editing for language evident but not complete.

no errors in the grammar presented in lesson; very few crrors in subjectverb or nouniadjective agreement; work was well edited for language. 
Henry

Espanol 102

Draft

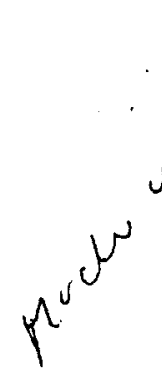

\section{$\underline{\text { El Asesinato }}$}

Claudia Reyes fue asesinato en 14 de marzo. Ese fue un Lunes. Ella estuvo da

acostado en piso cerca de la puerta. El correo estuvo enpiso. La puerta estuvo abierto El asesinato de,Senora Reyes ocurrió a las tres. Hay tres posibles sospechosos para el asesinato: el cartero, su marido y la empleada. El cartero es Ernesto Padilla. Su marido e\$ Arturo Reyes. La empleada es Dulce Ramos. El jurado y el juez escucharon a tres sospechosos. Arturo Reyes testificó primero. Luego Ernesto Padilla testificó. Finalmente Dulce Ramos testificó tercero. Todos de testimonios estuvieron diferente. Funon

Arturo Reyes dije el cartero fue enamorado de mi esposa. Pero Claudia no le gue esturo

gusta Ernesto. Claudia dijo "me gusta mi marido y no tú." El mes pasado Ernesto peleaba con_mï ${ }^{\nu} \mathrm{El}$ dijo "Yo iré matar usted y Claudia." Yo estuve al aire libre en Lunes. Luego ví Ernesto con un revólver. Después oí el cañoneo. Ernesto estuvo muy enojado. Él mato Łon arma cerca de puerta. Más tarde dejo la casa.

Ernesto Padilla dijo "en 14 de marzo yo fui en mi casa." Yo estuve muy enfermo estuve

el lunes. Estuve en mi cama todo el día. Mi esposa me dió medicina. Ella tomó mi tempertura a las tres. Mi gerente vino a mi casa a las tres y media. Como podre matar

Claudia cuando yo estuve en mi casa todo día. No tuve un revolver. Yo tuve nio razon ol morir Claudia.

Dulce Ramos dijo "ví Arturo matarjsu esposa." Él mató con arma Claudia. Estu vie en la puerta de la sala. Arturo estuvo muy enojado con Claudia. Ella tuvo un relación amoroasa con su doctor. Arturo escondió el revólver en el basurero. 
La policía funda el revólver ayer. Las huellas digitales de Arturo Reyes estuvo en encotió el revolver. El jurado dijo "Nosotros encuentramos Senor Reyes CULPABLE de el revolver. El jurado dijo "Nosotros encuentram

asesinato." El jurado creió la declaración de la empleada. Luego Arturo pusedde pie y dijo "Ella mereció morir. Ella durme con su doctor diez veces, la semana pasada. El juez sentenció Senor Reyes a vida en prisión.

$$
\text { a }
$$

de por 